
\title{
$\begin{array}{ll}\text { Research Square } & \begin{array}{l}\text { Preprints are preliminary reports that have not undergone peer review. } \\ \text { They should not be considered conclusive, used to inform clinical practice, } \\ \text { or referenced by the media as validated information. }\end{array}\end{array}$
}

\section{Exploration of Traditional Plant Based Medicines Used as Potential Remedies for Livestock Aliments in Northeastern Ethiopia}

\author{
Ahmed Hassen \\ Woldia University \\ Meseret Muche ( $\square$ muchemeseret@wldu.edu.et ) \\ Woldia University https://orcid.org/0000-0001-7879-3985 \\ Muthama Muasya \\ University of Cape Town \\ Berhanu Tsegay Abraha \\ Bahir Dar University
}

Research

Keywords: Agroclimatic zones, Ethnoveterinary, Livestock, Medicinal Plants, Traditional Lore

Posted Date: March 1st, 2021

DOl: https://doi.org/10.21203/rs.3.rs-250728/v1

License: (c) (7) This work is licensed under a Creative Commons Attribution 4.0 International License. Read Full License 


\section{Abstract \\ Background}

Livestock production is an integral part of the agricultural industry and to the livelihood of smallholder farmers in Ethiopia. However, livestock diseases and erosion of medicinal plants need urgent attention. Therefore this study was conducted to explore the ethnoveterinary plants and practices used to treat livestock ailments across varied agroclimatic zones in northeastern Ethiopia.

\section{Methods}

Information on the ethnoveterinary plants was collected between December 2019 and July 2020 across three districts using semi-structured questionnaire. The generated data included types of plants, parts used, preparations and routes of administration for treating livestock ailments. ANOVA and Chi-square were used to compute ethnoveterinarical indices among agroclimates.

\section{Results}

The present study revealed that there was a significant association $(P=0.001)$ between numbers of ethnoveterinary plant citations with sex, and age categories $(P=0.02)$, however, there were no considerable associations in educational status $(P=0.07)$. A total of 95 plants in 44 families were used by the healers for treatments of 45 livestock ailments. The ANOVA result showed that there was a significant difference in distribution of medicinal plant species $(P<0.01)$ in the agroclimatic zones. Irrespective of the variation, the most cited plant family with the largest number of species 10 (10.52\%) was Asteraceae and herbs 39 (42.8\%) were the dominant growth form reported. The most common plant part used for formulation of remedies was leaves $41(39.05 \%)$ and crushing and pounding were the dominant mode of preparations. Most of plants were from the wild 65(70.65\%) habitat. Considerable variations in Use Value (UV), Relative Frequency of Citations (RFC) and Fidelity Level (FL) were observed among the survived agroclimates. Datura stramonium (UV $=0.85 ; \mathrm{FL}=90.4 \% ; \mathrm{RFCs}=$ 0.8 ) was the most often cited species to treat livestock ailments. The highest ICF was observed for bloating (0.87), bloody diarrhea (0.85) and eye infection (0.84), respectively.

\section{Conclusions}

The studied districts are rich in both medicinal floras and concomitant traditional knowledge for the treatment of livestock ailments and therefore further studies on the phytochemical screening of ethnoveterinary plants is vital for inventory of pharmacological active ingredients and production of drugs.

\section{Background}

Livestock production is one of the main economic sources for the livelihoods of smallholder farmers and tribal communities [1,2]. It has sundry functions as a source of calories, income generation, medicine, rituals and ceremonies, input for crop production and raw material for industry $[1,3]$. Thus, ethnoveterinary (EV) lore is important alternative to maintain animal healthcare system and productivity $[4,5]$. It is concerned with the systematic investigation of the folk beliefs, knowledge, method and socio-cultural practices of the local community [6, 7]. It also explores the animal breeding and feeding system; traditional surgical techniques; magico-religious practices and so forth [8-10]. In fact, this practice has been experienced by the indigenous people for a century in a way of formulating and using herbal remedies to handle animal health care and increasing the quality of animal-based food products [7, 11]. As a result, the majority of the people in the world rely on folk medicine for mitigation of livestock diseases $[3,12]$. This is because most people in the developing countries are resourcepoor and cannot afford expensive synthetic drugs $[3,9,13]$. In addition, rural communities have easy access to medicinal plants suited for local diseases unlike synthetic drugs, which are inaccessible and expensive.

Various ethnoveterinary studies on indigenous knowledge of potential medicinal plants, isolation of bioactive compounds and prevention mechanisms have been reported in Europe [14-16], Asia [1, 2, 5], and is of raising importance in most developing countries [13, 17-23]. Despite these studies across the globe, the ailments; medicinal practices, nature of plants, frequency and mode of administration vary in relation to geography, time and knowledge [2]. In Ethiopia livestock production is an integral part of the agricultural industries [24], with an estimated population of 56.7 million cattle, 58.4 million sheep and goats, and 11.0 million equines (horses, donkeys, mules, camels) [25]. The sector contributes about $30-35 \%$ to the agricultural GDP and generates $12-15 \%$ of the total earnings [1]. However, the roles of livestock remain negligible because of epidemics and pandemics diseases [24, 26], coupled with erosion of ethnoveterinary plants and 
practices $[19,21]$. Diseases such as the anthrax, blackleg, lumpy skin disease (LSD), Sheep and Goat Pox, liver fluke etc., contribute to huge mortality, morbidity and great financial losses [27, 28]. According to FAO [1] in developing nation animal diseases and infections result in the huge production losses (30-35\%) and Ethiopia alone lost USD 35 million in the years 2010 to 2014 . This study focused on areas that have huge potential of livestock resources which accounted to be about $978,152.00[26,29]$. Thus explorations of ethnoveterinary knowledge could contribute to developing sustainable livestock disease management; conserve medicinal plant resources and potential source for drug production. This study is therefore aimed at identifying and documenting the indigenous knowledge of medicinal plants used to treat livestock disease in northern eastern Ethiopia. The research addressed the following questions.

1. Which medicinal plant species are most commonly used for the livestock ailments across the agroclimates?

2. Is there variation in ethnoveterinarical medicinal plants, usage and practices across agroclimatic zones?

3. Which types of livestock disease (s) is/are most frequently occurring in the localities?

4. Which medicinal part (s) is/are mostly used to treat livestock disease in the study districts?

\section{Materials And Methods Description of the study districts}

This explorative study was conducted in selected districts of North Wollo administrative zone, Amhara regional state northeastern Ethiopia

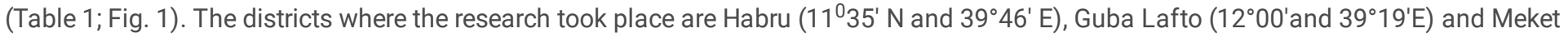
$\left(12^{\circ} 00^{\prime} \mathrm{N}\right.$ and $\left.38^{\circ} 44^{\prime} \mathrm{E}\right)$ areas (Fig. 1). These districts were selected based on the fact that agroclimatic zones support abundant medicinal floral and faunal resources composition and distribution [30,31], which could influence the ethnoveterinary practices [2]. Thus Habru district belongs to the hot agroclimatic zone, Gubalafto and Meket districts are temperate and cool agroclimatic zones, respectively (Table 1). In addition the local people here predominantly use medicinal plants as a primary health care system for their livestock. Regarding with the climatic condition, Guba Lafto and Meket districts have bi-modial rainfall pattern with an erratic distribution where minimum precipitation is mostly distributed from late March to early October and maximum rain is received in late June, July and August [32], whereas Habru has unimodal rainfall pattern where the maximum rainfall is received from late June to August and hence characterized by warm sub-moist climatic condition [32]. The main land cover types (LCTs) of the study districts are cultivated lands, forested lands, grazing lands and settlements [30]. According to CSC [25], majority of inhabitants 168, 816 (80.1\%) in Habru; 134, 939 (96.5 \%) Gubalafto and 214894 (94.8\%) Meket reside in the rural areas of the districts (Table 1), where poor facilities and inaccessibility of veterinary clinics and modern synthetic drugs and thus the rural communities chiefly depend on medicinal plant resources for the treatments of their livestock aliments. The communities in the rural areas of the districts are practicing mixed farming system that involves cultivation of crops (e.g. Hordeum vulgare, Triticum aestivum, Linum usitatissimum, Zea mays, Sorghum bicolor, Eragrostis tef) and livestock rearing. According to NWARD [29], the districts have a total of 818204 livestock population (Table 1), within the proportions of 396810 (48.5\%) cattle; 202333 (24.73 \%) goats; 127969 (15.64 \%) sheep; 68504 (8.37\%) donkeys; 17758 (2.17\%) camels; 2761(0.34 \%) horses; and 2069 (0.25\%) mules. In addition, the preliminary survey done between 2019 and 2020 and the information obtained from the districts veterinary centers and the local people indicated that the most common and prevalent livestock diseases are the abdominal pain, diarrhea, eye disease, unwanted abortion, retained placenta and wound. 
Table 1

The geographical description of the study districts based on agroclimatic zones $(n=3)$

\begin{tabular}{|llll|}
\hline Environmental Features & \multicolumn{2}{l}{ Study districts } & \\
\cline { 2 - 4 } & Habru & Gubalafto & Meket \\
\hline Agroclimates & Kolla & Woina dega & Dega \\
\hline Altitudinal Range & $700-1900 \mathrm{~m}$ & $1000-3000$ & $1300-3900 \mathrm{~m}$ \\
\hline Rainfall Range & $400-900 \mathrm{~mm}$ & $500-1050 \mathrm{~mm}$ & $500-1500 \mathrm{~mm}$ \\
\hline Temp. Range & $18-28.7^{0} \mathrm{C}$ & $18^{0}$ and $27^{0}$ & $14^{0}-26^{0} \mathrm{C}$ \\
\hline Area coverage & $1239.79 \mathrm{~km}{ }^{2}$ & $900.49 \mathrm{~km}^{2}$ & $1909.25 \mathrm{~km}^{2}$ \\
\hline Total Inhabitants & 210830 & 151308 & 81284 \\
\hline Total livestock population & 244715 & 231998 & 341491 \\
\hline (Hot (Kolla), temperate (Woina Dega), cool (Dega); NWARD [29] and Bekele [30] \\
\hline
\end{tabular}

\section{Sampling methods and data collection tools}

The study was carried between February and July 2020 after a reconnaissance survey was performed with the local people and districts veterinary clinics. In designing the survey, three-stage sampling procedures were used. The districts (Habru, Gubalafto and Meket) were first purposively selected based on having different agro-climatic zones namely hot (Habru), temperate (Gubalafto) and cool (Meket) (Table 1). Then four sites (Fig. 1) and 40 informants were identified for the survey in each of the district using random and snowball sampling techniques. The informants (Table 2) were selected based on recommendation by local authorities and religious leaders, and by their ethnoveterinary medicine practice and thus from the entire 120 sample informants (15) key informants were participated.

Consent was obtained from all informants before starting the study.

Interviews and semi-structured questionnaire were used for data collection. Accordingly, informants were interviewed on types of ethnoveterinary plants, growth habits, parts used, methods of preparation, routes of administration, disease treated, and management options using their vernacular language (Amharic). Plants not known to the researchers were collected, pressed and transported to Wodia University where identification was made. Resources like natural database for Africa (NDA) version 2.0 (http://www.htmlexe.com/) and Flora of Ethiopia and Eritrea publications [33-36] were consulted specimen identification. 
Table 2

Household characteristics of sample respondents $(\mathrm{N}=120)$

\begin{tabular}{|c|c|c|c|c|c|c|c|}
\hline \multicolumn{2}{|c|}{ Household Characteristics } & \multicolumn{3}{|c|}{ No of Respondents in each of Study Communities } & \multirow[t]{2}{*}{ Frequency } & \multirow[t]{2}{*}{ Percent } & \multirow{2}{*}{$\begin{array}{l}\text { Cumulative } \\
\%\end{array}$} \\
\hline & & $\begin{array}{l}\text { Habru }(n= \\
40)\end{array}$ & $\begin{array}{l}\text { Gubalafto }(n= \\
\text { 40) }\end{array}$ & $\begin{array}{l}\text { Meket }(n= \\
40)\end{array}$ & & & \\
\hline \multirow[t]{2}{*}{ Sex } & Male & 35 & 32 & 31 & 98 & 81.67 & 81.67 \\
\hline & Female & 5 & 8 & 9 & 22 & 18.33 & 100.00 \\
\hline \multirow[t]{4}{*}{ Age } & $30-40$ years & 5 & 6 & 4 & 15 & 12.5 & 12.5 \\
\hline & $41-50$ years & 8 & 11 & 10 & 29 & 24.17 & 36.67 \\
\hline & $51-60$ years & 15 & 14 & 16 & 45 & 37.5 & 74.17 \\
\hline & > 61 years & 12 & 9 & 10 & 31 & 25.83 & 100.00 \\
\hline \multirow[t]{4}{*}{ Educational Status } & Tertiary schoolings & 6 & 7 & 5 & 18 & 15 & 15 \\
\hline & $\begin{array}{l}\text { Secondary } \\
\text { schoolings }\end{array}$ & 10 & 7 & 11 & 28 & 23.33 & 38.33 \\
\hline & Primary schoolings & 14 & 13 & 15 & 42 & 35 & 73.33 \\
\hline & $\begin{array}{l}\text { No formal } \\
\text { schoolings }\end{array}$ & 10 & 13 & 9 & 32 & 26.67 & 100.00 \\
\hline \multirow[t]{4}{*}{ Marital status } & Married & 36 & 32 & 35 & 103 & 85.83 & 85.83 \\
\hline & Unmarried & 1 & 6 & 2 & 9 & 7.5 & 93.33 \\
\hline & Divorce & 1 & 2 & 2 & 5 & 4.17 & 97.5 \\
\hline & Widowed & 2 & 0 & 1 & 3 & 2.5 & 100.00 \\
\hline \multirow{3}{*}{$\begin{array}{l}\text { Occupational } \\
\text { Status }\end{array}$} & Farmers & 22 & 26 & 20 & 68 & 56.67 & 56.67 \\
\hline & TMP & 7 & 4 & 5 & 16 & 13.33 & 70 \\
\hline & Others & 11 & 10 & 15 & 36 & 30 & 100.00 \\
\hline \multirow[t]{4}{*}{ No. of Livestock } & None & 3 & 6 & 3 & 12 & 10 & 10 \\
\hline & $1-5$ & 12 & 14 & 10 & 36 & 30 & 40 \\
\hline & $6-10$ & 16 & 15 & 16 & 47 & 39.17 & 79.17 \\
\hline & $>10$ & 9 & 5 & 11 & 25 & 20.83 & 100.00 \\
\hline
\end{tabular}

\section{Statistical analysis}

The collected quantitative ethnoveterinarical data were analyzed using descriptive statistics. Analysis of Variance (One - way- ANOVA) was employed to compare the effect of agroclimatic zones on the medicinal plants composition and related parameters using IBM SPSS (version 26, IBM, Armonk, NY, USA). In addition, Chi-square was employed to analyze the association of medicinal plants citations with selected socio-demographic factors. The ethnoveterinarical data analysis of Use Value (UV), Informant Consensus Factor (ICF), Fidelity Level (FL) and Relative Frequency of Citations (RFCs) were computed following the methods of Phillips et al. [37], Martin [38], Alexiades [39]. 
1. $\mathrm{UV}=\frac{\sum \mathrm{U}_{\mathrm{i}}}{\mathrm{Ni}} \mathrm{a}$ quantitative method used to assess the relative importance of species known by the local people. Where $\mathrm{Ui}$ is the number of uses mentioned by each informant $\mathrm{i}$ for a given species sand $\mathrm{Ni}$ is the total number of informants interviewed.

2. ICF $=$ Nur- Nt/ Nur-1 where Nt is number of taxa and Nur is number of use reports for each categories to check the level of homogeneity among the information provided by the practitioners.

3. $\mathrm{FL}(\%)=\frac{\mathrm{Np}}{\mathrm{N}} * 100$ : analysis of percentage of informants claiming the uses of a certain plant species for the same ailment to treat. Where $\mathrm{Np}$ is the number of informants that claim a use of plant to treat a particular disease and Nis the number of informants that use the plant as a medicine to treat any ailments.

4. $\mathrm{RFCs}=\mathrm{FCs} / \mathrm{N}$ : the relative frequency of citation reveals the local importance of each medicinal plant species as used by the indigenous people to the area. Where FC, is the number of informants who use the taxa and $\mathrm{N}$ is the total number of respondents of in the study ( $\mathrm{n}=40$ each district); $\mathrm{N}=120$ ).

\section{Results}

\section{The demographic characteristics of surveyed districts}

The socio-demographic information (sex, age, educational status, occupation and number of livestock) of the respondents interviewed during the ethnoveterinary survey of medicinal plants in the study areas is shown in the Table 2 . The results of the surveyed households illustrated that there were more male respondents, 98 (81.67\%) compared to females 22 (18.33\%). Age is an important variable which could tell the ethnoveterinarical experience, knowledge and practices of the respondents and thus mean age was found to be 48.4 years which falls within the range of 30-80 years (Table 2). In terms of education status, the majority of the respondents 42 (35 \%) have some schooling in primary education, but few respondents 18 (15\%) did attend tertiary education. Most of the surveyed respondents 68 (56.67 \%) were farmers whereas numbers of sample traditional medicinal practitioners were only 16 (13.33\%). The result also unveiled that the average number of livestock in the study districts was 4.07, ranging from 0 to 14 (Table 2). We also observed that there is significant association between the numbers of medicinal plants species cited and sex $X^{2}(7)=24.74, P=0.001$ (Fig. 2 ). Despite the variation in the sample individuals in terms of sex (Table 2), both genders cited almost equal proportion of ethnoveterinary plants (Fig. 2). The cross tabulated chi square revealed there was significant association amongst the number of cited medicinal plant species with the age categories $\left(X^{2}(12)=20.38, P=0.02, r^{2}=0.65\right)$, in which an increasing trends in the numbers or frequency of ethnoveterinary plants citation within increasing age categories was observed in this study (Fig. 2). However, lack of significant association has shown amongst the number of cited medicinal plant species and educational status $\left(X^{2}(15)=13.74, P=0.07, r^{2}=0.32\right)$ (Fig. 2). Yet, in the study the local people with no formal schooling have been cited for relatively large numbers of ethnoveterinary plants compared to the other educational classes

(Fig. 2).

\section{Ethnoveterinary plants diversity, habits and habitats}

The local people in the study districts are greatly dependent on the traditional medicinal plants for the treatment of animal diseases. Thus, out of the total surveyed individuals, more than $93(77.5 \%)$ relay on herbalists for the treatments of their livestock ailments, whilst very few $22(18.33 \%)$ of the respondents preferred veterinary clinics and others $5(4.17 \%)$.

And their medicinal knowledge was acquired from their forefathers through experience which has been transmitted orally from generation to generation 68 (56.67\%), by spiritual institutions 32 (26.67\%), from close relatives 16 (13.33\%) and others 4 (3.33\%).

Table 3 shows a total of 95 medicinal plant species distributed across 44 families were used to treat 45 livestock ailments in the surveyed agroclimatic zones. The ANOVA result revealed that there was a significant variation on medicinal plant species distribution $(\mathrm{F}=82.33, \mathrm{P}<$ 0.01 ) along the agroclimatic zones. Higher average medicinal plant species (60) were found in the hot agroclimatic zone (Habru) followed by temperate (53; Gubalafto) and cool (42; Meket) agroclimatic zonings (Table 4).Among the identified species, Asteraceae has the highest record of 10(10.52\%) species, followed by Fabaceae 9 (9.5\%), Euphorbiaceae 6 (6.32\%), Solanaceae 6 (6.32\%),Brassicaceae and Lamiaceae with five (5.26 \%) species each. The families Aloaceae, Amaranthaceae, Cucurbitaceae and Rosaceae had three (3.16\%) species each whilst the remaining eight and twenty six plant families were represented by two (2.11\%) and a single (1.05\%) species, respectively (Fig. 3; Table 3).In terms of growth habits, the most common species were herbs 39 (41.05\%) followed by shrubs 27 (28.4 \%) and tree $21(22.10 \%)$ whilst the climbers and parasitic plants species were only $7(7.4 \%)$ and 1 (1.05 \%), respectively (Fig. 4; Table 3).Majority of 
these medicinal plant resources were wild66 (69.47\%) in nature, followed by cultivated $19(20 \%)$ and very few $(10,10.53 \%)$ plant species were collected from both wild and cultivated habitats (Fig. 4; Table 3). 
Table 3

Lists of ethnoveterinary plants used to treat livestock diseases by the local people in three surveyed agroclimatic zonings

\begin{tabular}{|c|c|c|c|c|c|c|c|c|c|c|}
\hline No & Family Name & Botanical Name & $\begin{array}{l}\text { Vernacular } \\
\text { Name }\end{array}$ & $\mathrm{GH}$ & $\mathrm{Ha}$ & PU & $\begin{array}{l}\text { Ethnoveterinary } \\
\text { Use }\end{array}$ & $\begin{array}{l}\text { Traditional } \\
\text { usage }\end{array}$ & $\mathrm{Ra}$ & PAZ \\
\hline 1 & Fabaceae & $\begin{array}{l}\text { Acacia mellifera } \\
\text { (M.Vahl)Benth }\end{array}$ & & $\mathrm{T}$ & W & $\mathrm{B}$ & $\begin{array}{l}\text { Appetite } \\
\text { enhancer }\end{array}$ & $\begin{array}{l}\text { Its bark } \\
\text { crushed, } \\
\text { pounded and } \\
\text { mixed in water, } \\
\text { then a mixture } \\
\text { of it is given for } \\
\text { cattle }\end{array}$ & 0 & K \\
\hline 2 & Fabaceae & $\begin{array}{l}\text { Acacia nilotica } \\
\text { L. Delile }\end{array}$ & Gerare & $\mathrm{T}$ & W & $\mathrm{R}$ & Cough & $\begin{array}{l}\text { Its root is } \\
\text { crushed and } \\
\text { mixed within } \\
\text { water and then } \\
2-3 \text { glasses of } \\
\text { fusion are given } \\
\text { to the cattle }\end{array}$ & 0 & $\mathrm{~K}, \mathrm{WD}$ \\
\hline \multirow[t]{2}{*}{3} & Amaranthaceae & $\begin{array}{l}\text { Achyranthes } \\
\text { aspera }\end{array}$ & Telenj & $\mathrm{H}$ & W & $\mathrm{R}$ & Bleeding & $\begin{array}{l}\text { Crushed the } \\
\text { roots and tied } \\
\text { on bleeding } \\
\text { part }\end{array}$ & $D$ & WD \\
\hline & & & & & & & Bone fracture & $\begin{array}{l}\text { Crushed its root } \\
\text { together with } \\
\text { the roots of } \\
\text { Tragia brevipes, } \\
\text { Justicia } \\
\text { schimperiana, } \\
\text { mixed and tied } \\
\text { with cloth at the } \\
\text { injured parts of } \\
\text { the livestock }\end{array}$ & $\mathrm{D}$ & \\
\hline 4 & Fabaceae & $\begin{array}{l}\text { Albizia } \\
\text { schimperiana } \\
\text { Oliv. }\end{array}$ & & $\mathrm{T}$ & WC & $\mathrm{R}$ & Blackleg & $\begin{array}{l}\text { Powdered the } \\
\text { roots as well, } \\
\text { mixed with } \\
\text { water and } \\
\text { provide a glass } \\
\text { of the mixture } \\
\text { to cattle }\end{array}$ & 0 & $\begin{array}{l}\mathrm{K}, \mathrm{WD}, \\
\mathrm{D}\end{array}$ \\
\hline 5 & Aloaceae & $\begin{array}{l}\text { Aloe } \\
\text { macrocarpa }\end{array}$ & Eret & $\mathrm{H}$ & W & Lx & Wound & $\begin{array}{l}\text { Applied the } \\
\text { creamy on the } \\
\text { wound part of } \\
\text { for cattle, } \\
\text { sheep, goats } \\
\text { and equines till } \\
\text { recover. }\end{array}$ & $\mathrm{D}$ & $\mathrm{K}$ \\
\hline 6 & Aloaceae & $\begin{array}{l}\text { Aloe pubescens } \\
\text { Reynolds }\end{array}$ & & $\mathrm{H}$ & W & $\mathrm{R}$ & Anthrax & $\begin{array}{l}\text { Pounded the } \\
\text { root and mixed } \\
\text { with cold water } \\
\text { and half of a } \\
\text { litter is given to } \\
\text { cattle }\end{array}$ & 0 & $\mathrm{~K}$ \\
\hline 7 & Aloaceae & $\begin{array}{l}\text { Aloe vera } \mathrm{L} \text {. } \\
\text { Burm.F. }\end{array}$ & Eret & $\mathrm{H}$ & W & $\mathrm{R}$ & $\begin{array}{l}\text { Protect } \\
\text { unwanted } \\
\text { abortion }\end{array}$ & $\begin{array}{l}\text { Dry roots are } \\
\text { grounded and } \\
\text { mixed with } \\
\text { water and } 1 / 2 \\
\text { litter of the } \\
\text { mixture is given } \\
\text { in every } \\
\text { morning for } \\
\text { cattle }\end{array}$ & 0 & $\mathrm{~K}$ \\
\hline
\end{tabular}

Note: GH, Growth Habits (T, Tree; H, Herb; S, Shrub; C, Climbers and P, Parasitic); Ha, Habitats (W, Wild; C, Cultivated and WC, Wild and Cultivated); PU, Parts Used (L, Leaves; Sd, Seed; B, Bark; F, Fruits; S, Shoot; St, Stem; R, Root; Lx, Latex); RA, Routs of Applications (O, Oral; D, Dermal; ET, Ear Tube; Oc, Ocular; N, Nasal; Oral and Nasal (No) and T, Topical); PAZ, Preferred Agroclimatic Zone (K, Kolla or Hot, WD, Woina Dega or temperate, D, Dega or cool) 


\begin{tabular}{|c|c|c|c|c|c|c|c|c|c|c|}
\hline No & Family Name & Botanical Name & $\begin{array}{l}\text { Vernacular } \\
\text { Name }\end{array}$ & $\mathrm{GH}$ & $\mathrm{Ha}$ & PU & $\begin{array}{l}\text { Ethnoveterinary } \\
\text { Use }\end{array}$ & $\begin{array}{l}\text { Traditional } \\
\text { usage }\end{array}$ & $\mathbf{R a}$ & PAZ \\
\hline 8 & Amaranthaceae & $\begin{array}{l}\text { Amaranthus } \\
\text { caudatus } \mathrm{L} \text {. }\end{array}$ & Aluma & $\mathrm{H}$ & W & L & Diarrhea & $\begin{array}{l}\text { Pound the } \\
\text { leaves and } \\
\text { boiled the } \\
\text { pounded } \\
\text { together with } \\
\text { Allium sativum } \\
\text { and given ten } \\
\text { percent of its } \\
\text { dose to the } \\
\text { cattle }\end{array}$ & 0 & K \\
\hline \multirow[t]{2}{*}{9} & Papaveraceae & $\begin{array}{l}\text { Argemone } \\
\text { mexicanal L. }\end{array}$ & Yahyaeshoh & $\mathrm{H}$ & W & L & Neck pain & $\begin{array}{l}\text { Crushed the } \\
\text { fresh leaf, } \\
\text { mixed with } \\
\text { butter and } \\
\text { applied the } \\
\text { paste on the } \\
\text { affected } \\
\text { livestock part }\end{array}$ & $\mathrm{D}$ & $\begin{array}{l}\text { K, WD, } \\
\text { D }\end{array}$ \\
\hline & & & & & & $\mathrm{R}$ & Devil disease & $\begin{array}{l}\text { Crushed the } \\
\text { roots and } \\
\text { mixed with two } \\
\text { cup of tea and } \\
\text { given for cattle }\end{array}$ & No & \\
\hline 10 & Melianthaceae & $\begin{array}{l}\text { Bersama } \\
\text { abyssinica }\end{array}$ & Azamir & S & W & L & $\begin{array}{l}\text { Internal } \\
\text { Parasites }\end{array}$ & $\begin{array}{l}\text { The twig part of } \\
\text { leaf is crushed } \\
\text { and powdered, } \\
\text { then boiled with } \\
\text { tea and drunk } \\
\text { for livestock }\end{array}$ & 0 & K \\
\hline 11 & Brassicaceae & $\begin{array}{l}\text { Brassica } \\
\text { carinata }\end{array}$ & Gomen Zer & $\mathrm{H}$ & $\mathrm{C}$ & $\mathrm{Sd}$ & Stomach ache & $\begin{array}{l}\text { Ground, mixed } \\
\text { with water as } \\
\text { well, and then } \\
\text { given to the } \\
\text { cattle }\end{array}$ & 0 & $\begin{array}{l}\mathrm{K}, \mathrm{WD}, \\
\mathrm{D}\end{array}$ \\
\hline 12 & Brassicaceae & Brassica nigra & Senafich & $\mathrm{H}$ & C & $\mathrm{Sd}$ & Stomach worm & $\begin{array}{l}\text { Seeds are } \\
\text { crushed to } \\
\text { powdery, mixed } \\
\text { with water and } \\
\text { then given in } \\
\text { every morning } \\
\text { to cattle }\end{array}$ & 0 & $\begin{array}{l}\mathrm{K}, \mathrm{WD}, \\
\mathrm{D}\end{array}$ \\
\hline 13 & Brassicaceae & $\begin{array}{l}\text { Bridella } \\
\text { micrantha }\end{array}$ & Gomen & $\mathrm{H}$ & C & B & Expel placenta & $\begin{array}{l}\text { Crushed the } \\
\text { barks, mixed } \\
\text { with water and } \\
\text { given a glass of } \\
\text { the extract to } \\
\text { the livestock }\end{array}$ & 0 & $\begin{array}{l}\mathrm{K}, \mathrm{WD}, \\
\mathrm{D}\end{array}$ \\
\hline 14 & Simaroubaceae & $\begin{array}{l}\text { Brucea } \\
\text { antidysenterica }\end{array}$ & $\begin{array}{l}\text { yedaga } \\
\text { abalo }\end{array}$ & $\mathrm{H}$ & W & L & Skin rash & $\begin{array}{l}\text { Powdered the } \\
\text { leaves mixed } \\
\text { with butter and } \\
\text { applied creamy } \\
\text { on the rash part } \\
\text { of cattle body }\end{array}$ & $\mathrm{D}$ & D \\
\hline 15 & Fabaceae & Calpurnia aurea & Digita & S & WC & L & $\begin{array}{l}\text { External } \\
\text { parasites }\end{array}$ & $\begin{array}{l}\text { Grained the } \\
\text { leaves and then } \\
\text { wash the cattle } \\
\text { thoroughly until } \\
\text { the parasites } \\
\text { are removed }\end{array}$ & D & WD \\
\hline
\end{tabular}

Note: GH, Growth Habits (T, Tree; H, Herb; S, Shrub; C, Climbers and P, Parasitic); Ha, Habitats (W, Wild; C, Cultivated and WC, Wild and Cultivated); PU, Parts Used (L, Leaves; Sd, Seed; B, Bark; F, Fruits; S, Shoot; St, Stem; R, Root; Lx, Latex); RA, Routs of Applications (O, Oral; D, Dermal; ET, Ear Tube; Oc, Ocular; N, Nasal; Oral and Nasal (No) and T, Topical); PAZ, Preferred Agroclimatic Zone (K, Kolla or Hot, WD, Woina Dega or temperate, D, Dega or cool) 


\begin{tabular}{|c|c|c|c|c|c|c|c|c|c|c|}
\hline No & Family Name & Botanical Name & $\begin{array}{l}\text { Vernacular } \\
\text { Name }\end{array}$ & $\mathrm{GH}$ & $\mathrm{Ha}$ & PU & $\begin{array}{l}\text { Ethnoveterinary } \\
\text { Use }\end{array}$ & $\begin{array}{l}\text { Traditional } \\
\text { usage }\end{array}$ & $\mathbf{R a}$ & PAZ \\
\hline 16 & Asteraceae & $\begin{array}{l}\text { Cirsium } \\
\text { englerianium }\end{array}$ & $\begin{array}{l}\text { Yahya } \\
\text { kusheshili }\end{array}$ & $\mathrm{H}$ & W & $\mathrm{R}$ & Bloating & $\begin{array}{l}\text { Pound the root, } \\
\text { mixed with } \\
\text { water and given } \\
\text { to cattle }\end{array}$ & 0 & K \\
\hline 17 & Vitaceae & $\begin{array}{l}\text { Cissus } \\
\text { quadrangularis }\end{array}$ & $\begin{array}{l}\text { Yezehon } \\
\text { Anjet }\end{array}$ & C & W & $\mathrm{R}$ & Diarrhea & $\begin{array}{l}\text { Grained the } \\
\text { roots very well, } \\
\text { mixed with } \\
\text { water and } \\
\text { provide half } \\
\text { litter in every } \\
\text { morning for } \\
\text { three } \\
\text { subsequent } \\
\text { days }\end{array}$ & 0 & WD \\
\hline 18 & Ranunculaceae & $\begin{array}{l}\text { Clematis } \\
\text { simensis Fresen }\end{array}$ & Azoareg & $\mathrm{C}$ & W & L & Wound & $\begin{array}{l}\text { Crushed the } \\
\text { leaves, creamed } \\
\text { and applied the } \\
\text { fluid to the } \\
\text { affected parts } \\
\text { for livestock }\end{array}$ & $\mathrm{D}$ & D \\
\hline 19 & Euphorbiaceae & $\begin{array}{l}\text { Clutia } \\
\text { abyssinica } \\
\text { Jaub.\&Spanch }\end{array}$ & Fyelefej & S & W & L & Anthrax & $\begin{array}{l}\text { Squeeze the } \\
\text { fresh leaves, } \\
\text { mixed with } \\
\text { water, drenched } \\
\text { and then given } \\
\text { to the cattle }\end{array}$ & 0 & D \\
\hline 20 & Euphorbiaceae & $\begin{array}{l}\text { Clutia } \\
\text { lanceolata }\end{array}$ & Fiyelefej & $S$ & W & L & Bloating & $\begin{array}{l}\text { Pound the } \\
\text { leaves, mixed } \\
\text { with water and } \\
\text { given to cattle, } \\
\text { sheep and } \\
\text { goats }\end{array}$ & 0 & D \\
\hline 21 & Rubiaceae & $\begin{array}{l}\text { Coffee } \\
\text { abica L. }\end{array}$ & Buna & S & C & $\mathrm{Sd}$ & Castration & $\begin{array}{l}\text { Roasted seeds } \\
\text { are crushed, } \\
\text { pounded well, } \\
\text { boiled with } \\
\text { water and allow } \\
\text { the camel to } \\
\text { drink. }\end{array}$ & 0 & $\mathrm{~K}, \mathrm{WD}$ \\
\hline 22 & Burseraceae & $\begin{array}{l}\text { Commiphora } \\
\text { africana }\end{array}$ & Ankeva & $\mathrm{T}$ & W & L & Tick & $\begin{array}{l}\text { Crushed the } \\
\text { leaves and } \\
\text { made the juice } \\
\text { to creamed on } \\
\text { the skin of } \\
\text { goats, sheep } \\
\text { and cattle }\end{array}$ & $\mathrm{D}$ & K \\
\hline 23 & Boraginaceae & Cordia africana & Wanza & $\mathrm{T}$ & WC & L & Ear mites & $\begin{array}{l}\text { Pound, squeeze } \\
\text { the crushed } \\
\text { leaves and } \\
\text { inserted into ear } \\
\text { tube of cattle }\end{array}$ & $\mathrm{ET}$ & $\begin{array}{l}\text { K,WD, } \\
\text { D }\end{array}$ \\
\hline 24 & Capparidaceae & $\begin{array}{l}\text { Crateva } \\
\text { adansonii Dc. }\end{array}$ & & S & W & $\mathrm{R}$ & Anthrax & $\begin{array}{l}\text { Its root with the } \\
\text { leaf of Croton } \\
\text { macrostchyus } \\
\text { are pounded, } \\
\text { mixed with } \\
\text { water, and } 1 / 2 \\
\text { litter is given to } \\
\text { cattle }\end{array}$ & 0 & K \\
\hline
\end{tabular}

Note: GH, Growth Habits (T, Tree; H, Herb; S, Shrub; C, Climbers and P, Parasitic); Ha, Habitats (W, Wild; C, Cultivated and WC, Wild and Cultivated); PU, Parts Used (L, Leaves; Sd, Seed; B, Bark; F, Fruits; S, Shoot; St, Stem; R, Root; Lx, Latex); RA, Routs of Applications (O, Oral; $\mathrm{D}$, Dermal; ET, Ear Tube; Oc, Ocular; N, Nasal; Oral and Nasal (No) and T, Topical); PAZ, Preferred Agroclimatic Zone (K, Kolla or Hot, WD, Woina Dega or temperate, D, Dega or cool) 


\begin{tabular}{|c|c|c|c|c|c|c|c|c|c|c|}
\hline No & Family Name & Botanical Name & $\begin{array}{l}\text { Vernacular } \\
\text { Name }\end{array}$ & GH & $\mathrm{Ha}$ & PU & $\begin{array}{l}\text { Ethnoveterinary } \\
\text { Use }\end{array}$ & $\begin{array}{l}\text { Traditional } \\
\text { usage }\end{array}$ & $\mathrm{Ra}$ & PAZ \\
\hline 25 & Asteraceae & Crepis rueppellii & & $\mathrm{H}$ & W & $\mathrm{R}$ & Anthrax & $\begin{array}{l}\text { Crushed, mixed } \\
\text { with water, and } \\
\text { applied a half } \\
\text { litter to cattle }\end{array}$ & 0 & $\mathrm{~K}$ \\
\hline 26 & Fabaceae & $\begin{array}{l}\text { Crotalaria } \\
\text { karagulensis }\end{array}$ & Yeayt ater & $\mathrm{H}$ & W & $\mathrm{L}$ & Skin itching & $\begin{array}{l}\text { Crushed into } \\
\text { powdery and } \\
\text { applied the } \\
\text { butter mixed } \\
\text { creamy leaves } \\
\text { on to the } \\
\text { affected body } \\
\text { part of the } \\
\text { cattle }\end{array}$ & $\mathrm{D}$ & WD \\
\hline \multirow[t]{2}{*}{27} & Euphorbiaceae & $\begin{array}{l}\text { Croton } \\
\text { macrostachyus }\end{array}$ & Bisana & $\mathrm{T}$ & W & $\mathrm{L}$ & Ringworms & $\begin{array}{l}\text { Creamed the } \\
\text { latex to the } \\
\text { infected cattle }\end{array}$ & $\mathrm{D}$ & $\begin{array}{l}\mathrm{K}, \mathrm{WD} \\
\mathrm{D}\end{array}$ \\
\hline & & & & & & & Wound & $\begin{array}{l}\text { Squeeze fresh } \\
\text { leaf, mixed with } \\
\text { water and then } \\
\text { half of a litter is } \\
\text { given to cattle } \\
\text { in every } \\
\text { morning }\end{array}$ & 0 & \\
\hline \multirow[t]{2}{*}{28} & Cucurbitaceae & $\begin{array}{l}\text { Cucumis } \\
\text { ficifolius A.Rich }\end{array}$ & $\begin{array}{l}\text { Yemdr } \\
\text { Emboy }\end{array}$ & $\mathrm{C}$ & W & $\mathrm{R}$ & $\begin{array}{l}\text { Bloody } \\
\text { Diarrhea }\end{array}$ & $\begin{array}{l}\text { Crushed, } \\
\text { powdered, } \\
\text { mixed with } \\
\text { milk, and } 1 / 3 \text { of } \\
\text { the mixtures is } \\
\text { given to the } \\
\text { cattle, goat and } \\
\text { sheep }\end{array}$ & 0 & $\begin{array}{l}\mathrm{K}, \mathrm{WD} \\
\mathrm{D}\end{array}$ \\
\hline & & & & & & & Bloating & $\begin{array}{l}\text { Crushed, mixed } \\
\text { with milk and } \\
\text { allow to drink at } \\
\text { once (cattle) }\end{array}$ & 0 & \\
\hline 29 & Cucurbitaceae & Cucurbita pepo & Duba & $\mathrm{C}$ & $\mathrm{C}$ & $\mathrm{F}$ & Expel placenta & $\begin{array}{l}\text { Chopped, boiled } \\
\text { and half of litter } \\
\text { is given to } \\
\text { cattle, goat and } \\
\text { sheep }\end{array}$ & 0 & $\begin{array}{l}\mathrm{K}, \mathrm{WD} \\
\mathrm{D}\end{array}$ \\
\hline 30 & Amaranthaceae & $\begin{array}{l}\text { Cyathula } \\
\text { prostrate }\end{array}$ & Aregist & $\mathrm{H}$ & W & $\mathrm{L}$ & Anthrax & $\begin{array}{l}\text { Crushed, } \\
\text { squeezed and a } \\
\text { litter of the } \\
\text { mixture is given } \\
\text { to the infected } \\
\text { cattle }\end{array}$ & 0 & $\mathrm{~K}$ \\
\hline 31 & Boraginaceae & $\begin{array}{l}\text { Cynoglossum } \\
\text { lanceolatum }\end{array}$ & Chegogit & $\mathrm{H}$ & W & $\mathrm{R}$ & Mastitis & $\begin{array}{l}\text { Chopped, } \\
\text { crushed, mixed } \\
\text { with butter and } \\
\text { given to the } \\
\text { cow }\end{array}$ & $\mathrm{T}$ & WD \\
\hline 32 & Solanaceae & $\begin{array}{l}\text { Datura } \\
\text { stramonium L. }\end{array}$ & Astenagir & $\mathrm{H}$ & W & $\mathrm{L}$ & Wound & $\begin{array}{l}\text { Crush the fresh } \\
\text { leaves, chewed, } \\
\text { applied the } \\
\text { extracts on the } \\
\text { affected body } \\
\text { parts of all } \\
\text { livestock }\end{array}$ & $\mathrm{D}$ & $\begin{array}{l}\mathrm{K}, \mathrm{WD}, \\
\mathrm{D}\end{array}$ \\
\hline
\end{tabular}

Note: GH, Growth Habits (T, Tree; H, Herb; S, Shrub; C, Climbers and P, Parasitic); Ha, Habitats (W, Wild; C, Cultivated and WC, Wild and Cultivated); PU, Parts Used (L, Leaves; Sd, Seed; B, Bark; F, Fruits; S, Shoot; St, Stem; R, Root; Lx, Latex); RA, Routs of Applications (O, Oral; D, Dermal; ET, Ear Tube; Oc, Ocular; N, Nasal; Oral and Nasal (No) and T, Topical); PAZ, Preferred Agroclimatic Zone (K, Kolla or Hot, WD, Woina Dega or temperate, D, Dega or cool) 


\begin{tabular}{|c|c|c|c|c|c|c|c|c|c|c|}
\hline No & Family Name & Botanical Name & $\begin{array}{l}\text { Vernacular } \\
\text { Name }\end{array}$ & GH & $\mathrm{Ha}$ & PU & $\begin{array}{l}\text { Ethnoveterinary } \\
\text { Use }\end{array}$ & $\begin{array}{l}\text { Traditional } \\
\text { usage }\end{array}$ & $\mathrm{Ra}$ & PAZ \\
\hline 33 & Sapindaceae & $\begin{array}{l}\text { Dodinia } \\
\text { angustifolia L.F }\end{array}$ & Kitkta & S & W & S & Broken bone & $\begin{array}{l}\text { The twig part of } \\
\text { stem with its } \\
\text { leaf are tied on } \\
\text { to the broken } \\
\text { part until } \\
\text { recovery }\end{array}$ & D & D \\
\hline 34 & Asteraceae & $\begin{array}{l}\text { Echinops } \\
\text { kebericho } \\
\text { Mesfin. }\end{array}$ & Kebericho & $\mathrm{H}$ & W & $\mathrm{R}$ & $\begin{array}{l}\text { Respiratory } \\
\text { infection }\end{array}$ & $\begin{array}{l}\text { Crushed the } \\
\text { root parts, } \\
\text { powdered and } \\
\text { smoke the } \\
\text { cattle until the } \\
\text { respiratory } \\
\text { infection or } \\
\text { manifestations } \\
\text { is stopped }\end{array}$ & No & WD \\
\hline 35 & Lamiaceae & $\begin{array}{l}\text { Ekebergia } \\
\text { capensis sparrm }\end{array}$ & Senbo & $T$ & WC & L & $\begin{array}{l}\text { Thinning } \\
\text { disease }\end{array}$ & $\begin{array}{l}\text { Crushed } \\
\text { together with } \\
\text { the leaf of } \\
\text { Dodonaea } \\
\text { angustifolia, } \\
\text { soaked for a } \\
\text { week in water } \\
\text { and given for } \\
3-5 \\
\text { subsequent } \\
\text { days }\end{array}$ & 0 & K \\
\hline 36 & Fabaceae & $\begin{array}{l}\text { Erythrina } \\
\text { abyssinica }\end{array}$ & Kura & $\mathrm{T}$ & C & B & Fibril illness & $\begin{array}{l}\text { Crushed } \\
\text { together with } \\
\text { leaf of Ruta } \\
\text { chalepensis } \\
\text { and bulb of } \\
\text { Allium sativum, } \\
\text { boil with water } \\
\text { and fumigate } \\
\text { the entire body } \\
\text { of the cattle }\end{array}$ & $\mathrm{D}$ & WD, $\mathrm{K}$ \\
\hline \multirow[t]{2}{*}{37} & Fabaceae & $\begin{array}{l}\text { Erythrina brucei } \\
\text { Schweinf. }\end{array}$ & Korch & $T$ & W & B & Bloating & $\begin{array}{l}\text { Pounded the } \\
\text { with the leaves } \\
\text { of Teclea } \\
\text { nobilis, mixed } \\
\text { with water and } \\
\text { a litter of the } \\
\text { mixture is given } \\
\text { to the equines }\end{array}$ & 0 & WD \\
\hline & & & & & & $\mathrm{R}$ & Eye disease & $\begin{array}{l}\text { Its root with the } \\
\text { leaf of Premna } \\
\text { resinosa are } \\
\text { pounded } \\
\text { together, filtered } \\
\text { and added once } \\
\text { five drops of } \\
\text { the filtrate to } \\
\text { cattle eye }\end{array}$ & Oc & \\
\hline 38 & Ebenaceae & $\begin{array}{l}\text { Euclea } \\
\text { racemosa }\end{array}$ & Dedeho & S & W & $\mathrm{R}$ & Eye disease & $\begin{array}{l}\text { Pulverized into } \\
\text { powdery, mixed } \\
\text { the creamy with } \\
\text { butter and } \\
\text { applied on the } \\
\text { infected eye of } \\
\text { the cattle }\end{array}$ & Oc & WD \\
\hline
\end{tabular}

Note: GH, Growth Habits (T, Tree; H, Herb; S, Shrub; C, Climbers and P, Parasitic); Ha, Habitats (W, Wild; C, Cultivated and WC, Wild and Cultivated); PU, Parts Used (L, Leaves; Sd, Seed; B, Bark; F, Fruits; S, Shoot; St, Stem; R, Root; Lx, Latex); RA, Routs of Applications (O, Oral; D, Dermal; ET, Ear Tube; Oc, Ocular; N, Nasal; Oral and Nasal (No) and T, Topical); PAZ, Preferred Agroclimatic Zone (K, Kolla or Hot, WD, Woina Dega or temperate, D, Dega or cool) 


\begin{tabular}{|c|c|c|c|c|c|c|c|c|c|c|}
\hline No & Family Name & Botanical Name & $\begin{array}{l}\text { Vernacular } \\
\text { Name }\end{array}$ & GH & $\mathrm{Ha}$ & PU & $\begin{array}{l}\text { Ethnoveterinary } \\
\text { Use }\end{array}$ & $\begin{array}{l}\text { Traditional } \\
\text { usage }\end{array}$ & $\mathrm{Ra}$ & PAZ \\
\hline 39 & Euphorbiaceae & $\begin{array}{l}\text { Euphorbia } \\
\text { tirucalii }\end{array}$ & Kinchib & S & WC & $\mathrm{Lx}$ & Wound & $\begin{array}{l}\text { Its latex is } \\
\text { creamed on the } \\
\text { wounded site of } \\
\text { donkey }\end{array}$ & D & K \\
\hline 40 & Rutaceae & $\begin{array}{l}\text { Fagaropsis } \\
\text { angolensis }\end{array}$ & - & $\mathrm{T}$ & W & B & Babesiosis & $\begin{array}{l}\text { Chopped the } \\
\text { bark, mixed } \\
\text { with water, } \\
\text { filtered and } \\
\text { given to the } \\
\text { cattle }\end{array}$ & 0 & K \\
\hline 41 & Brassicaceae & $\begin{array}{l}\text { Fagropsis } \\
\text { angoleusis }\end{array}$ & Feto & $\mathrm{H}$ & C & $\mathrm{Sd}$ & $\begin{array}{l}\text { Respiratory } \\
\text { infection }\end{array}$ & $\begin{array}{l}\text { Pounded, mixed } \\
\text { with water and } \\
\text { half of a litter is } \\
\text { given to cattle } \\
\text { for three days } \\
\text { in every } \\
\text { morning }\end{array}$ & 0 & $\begin{array}{l}\mathrm{K}, \mathrm{WD} \\
\mathrm{D}\end{array}$ \\
\hline 42 & Apiaceae & $\begin{array}{l}\text { Ferula } \\
\text { communis }\end{array}$ & Dog & $\mathrm{H}$ & W & $\mathrm{R}$ & $\begin{array}{l}\text { Increase sexual } \\
\text { need }\end{array}$ & $\begin{array}{l}\text { Pounded, mixed } \\
\text { with butter and } \\
\text { given the } \\
\text { creamed bread } \\
\text { to the cattle }\end{array}$ & 0 & D \\
\hline 43 & Flacourtiaceae & $\begin{array}{l}\text { Flacourtia } \\
\text { indica (Burm. f) } \\
\text { J Merr. }\end{array}$ & - & $\mathrm{T}$ & W & L & Pasteurollosis & $\begin{array}{l}\text { Crushed leaves } \\
\text { mixed with } \\
\text { water, filtrated } \\
\text { and given to } \\
\text { cattle once a } \\
\text { day }\end{array}$ & 0 & WD, $\mathrm{K}$ \\
\hline 44 & Tiliaceae & $\begin{array}{l}\text { Grewia } \\
\text { ferruginea }\end{array}$ & Lenquata & $S$ & W & B & Expel placenta & $\begin{array}{l}\text { Crushed, } \\
\text { powdered and } \\
\text { then given } 1 / 3 \\
\text { of watery } \\
\text { mixture to } \\
\text { livestock }\end{array}$ & 0 & D \\
\hline 45 & Rosaceae & $\begin{array}{l}\text { Hagenia } \\
\text { abyssinica L. }\end{array}$ & Kosso & $\mathrm{T}$ & W & $\mathrm{F}$ & Tape worm & $\begin{array}{l}\text { The female } \\
\text { flowers crushed } \\
\text { with its seed } \\
\text { together, mixed } \\
\text { in water and } 1 / 2 \\
\text { litters is given } \\
\text { for } 2-3 \text { days. }\end{array}$ & 0 & D \\
\hline 46 & Asteraceae & $\begin{array}{l}\text { Inula } \\
\text { confertiflora } \\
\text { A.Rich }\end{array}$ & Wenagft & S & W & $\mathrm{L}$ & Eye infection & $\begin{array}{l}\text { Crushed, } \\
\text { squeezed and } \\
\text { applied tree } \\
\text { drops of fluid } \\
\text { on the infection } \\
\text { eye surface for } \\
\text { three days }\end{array}$ & Oc & WD \\
\hline 47 & Acanthaceae & $\begin{array}{l}\text { Justicia } \\
\text { schimperiana }\end{array}$ & Sensel & S & w & $\mathrm{L}$ & $\begin{array}{l}\text { External } \\
\text { parasite }\end{array}$ & $\begin{array}{l}\text { Directly wash } \\
\text { the cattle with } \\
\text { water }\end{array}$ & D & D \\
\hline 48 & Crassulaceae & $\begin{array}{l}\text { Kalanchoe } \\
\text { laciniata }\end{array}$ & Endahula & $\mathrm{H}$ & w & S & Bloating & $\begin{array}{l}\text { Pulverize and } \\
\text { applied on the } \\
\text { swollen or } \\
\text { inflamed part of } \\
\text { cattle }\end{array}$ & D & D \\
\hline 49 & Crassulaceae & $\begin{array}{l}\text { Kalanchoe } \\
\text { petitiana A. Rich }\end{array}$ & Busike & $S$ & w & St & Wound & $\begin{array}{l}\text { Pounded, mixed } \\
\text { with water, and } \\
\text { then washed } \\
\text { the sore }\end{array}$ & D & D \\
\hline \multicolumn{11}{|c|}{$\begin{array}{l}\text { Note: GH, Growth Habits (T, Tree; H, Herb; S, Shrub; C, Climbers and P, Parasitic); Ha, Habitats (W, Wild; C, Cultivated and WC, Wild and } \\
\text { Cultivated); PU, Parts Used'(L, Leaves; Sd, Seed; B, Bark; F, Fruits; S, Shoot; St, Stem; R, Root; LX, Latex); RA, Routs of Applications (O, Oral } \\
\text { D, Dermal; ET, Ear Tube; Oc, Ocular; N, Nasal; Oral and Nasal (No) and T, Topical); PAZ, Preferred Agroclimatic Zone (K, Kolla or Hot, WD, } \\
\text { Woina Dega or temperate, D, Dega or cool) }\end{array}$} \\
\hline
\end{tabular}




\begin{tabular}{|c|c|c|c|c|c|c|c|c|c|c|}
\hline No & Family Name & Botanical Name & $\begin{array}{l}\text { Vernacular } \\
\text { Name }\end{array}$ & GH & $\mathrm{Ha}$ & PU & $\begin{array}{l}\text { Ethnoveterinary } \\
\text { Use }\end{array}$ & $\begin{array}{l}\text { Traditional } \\
\text { usage }\end{array}$ & $\mathbf{R a}$ & PAZ \\
\hline & & & & & & $\mathrm{R}$ & $\begin{array}{l}\text { Lack of } \\
\text { appetite }\end{array}$ & $\begin{array}{l}\text { Pounded, mixed } \\
\text { with water and } \\
\text { provide half a } \\
\text { litter for two } \\
\text { days }\end{array}$ & 0 & \\
\hline \multirow[t]{2}{*}{50} & Asteraceae & $\begin{array}{l}\text { Lactuca } \\
\text { intermis }\end{array}$ & Dememerarit & $\mathrm{H}$ & W & $\mathrm{R}$ & Bone broken & $\begin{array}{l}\text { Tied the root on } \\
\text { the broken part } \\
\text { of cattle, sheep, } \\
\text { goat }\end{array}$ & D & K \\
\hline & & & & & & $\mathrm{Lx}$ & Tick bite & $\begin{array}{l}\text { Creamed the } \\
\text { body of the } \\
\text { cattle after the } \\
\text { ticks are } \\
\text { removed from } \\
\text { the body }\end{array}$ & & \\
\hline 51 & Brassicaceae & $\begin{array}{l}\text { Lepidium } \\
\text { sativum L. }\end{array}$ & Feto & $\mathrm{H}$ & C & $\mathrm{Sd}$ & Diarrhea & $\begin{array}{l}\text { Dry seeds are } \\
\text { pulverized, } \\
\text { mixed with oil } \\
\text { and half of litter } \\
\text { is given in } \\
\text { morning for } \\
\text { three days for } \\
\text { cattle }\end{array}$ & 0 & $\begin{array}{l}\mathrm{K}, \mathrm{WD}, \\
\mathrm{D}\end{array}$ \\
\hline 52 & Lineaceae & $\begin{array}{l}\text { Linum } \\
\text { usitatissimum } \\
\text { L. }\end{array}$ & Talba & $\mathrm{H}$ & C & $\mathrm{Sd}$ & Expel placenta & $\begin{array}{l}\text { Powdered the } \\
\text { seeds, mixed } \\
\text { with water and } \\
\text { given a glass of } \\
\text { the blend for } \\
\text { cow, goats and } \\
\text { sheep }\end{array}$ & 0 & D \\
\hline \multirow[t]{2}{*}{53} & Fabaceae & $\begin{array}{l}\text { Millettia } \\
\text { ferruginea }\end{array}$ & Birbira & $\mathrm{T}$ & W & L & Leech & $\begin{array}{l}\text { Crushed, mixed } \\
\text { with water and } \\
1 / 2 \text { liters is } \\
\text { given once for } \\
\text { livestock to } \\
\text { expel the leech }\end{array}$ & 0 & $\mathrm{~K}, \mathrm{WD}$ \\
\hline & & & & & & $\mathrm{F}$ & Ringworm & $\begin{array}{l}\text { Crushed, mixed } \\
\text { with little water } \\
\text { and creamed } \\
\text { on skin. }\end{array}$ & $\mathrm{D}$ & \\
\hline 54 & Cucurbitaceae & $\begin{array}{l}\text { Momordica } \\
\text { foetida }\end{array}$ & Kurahareg & C & W & L & Sun stroke & $\begin{array}{l}\text { Grained the } \\
\text { leaves, mixed } \\
\text { with water and } \\
\text { creamed rash } \\
\text { parts of the } \\
\text { equines }\end{array}$ & $\begin{array}{l}0 \\
D\end{array}$ & K \\
\hline 55 & Myricaceae & $\begin{array}{l}\text { Myrica } \\
\text { salicifolia }\end{array}$ & Shinet & $\mathrm{T}$ & W & L & Eye infection & $\begin{array}{l}\text { Powdered and } \\
\text { applied on the } \\
\text { infection site } \\
\text { for three days }\end{array}$ & Oc & K \\
\hline 56 & Solanaceae & $\begin{array}{l}\text { Nicotiana } \\
\text { tabacum }\end{array}$ & Tinbaho & $\mathrm{H}$ & WC & L & Cough & $\begin{array}{l}\text { Crushed, } \\
\text { pounded and } \\
\text { smoked it with } \\
\text { their nose } \\
\text { (livestock) }\end{array}$ & $\mathrm{N}$ & WD \\
\hline
\end{tabular}

Note: GH, Growth Habits (T, Tree; H, Herb; S, Shrub; C, Climbers and P, Parasitic); Ha, Habitats (W, Wild; C, Cultivated and WC, Wild and Cultivated); PU, Parts Used (L, Leaves; Sd, Seed; B, Bark; F, Fruits; S, Shoot; St, Stem; R, Root; Lx, Latex); RA, Routs of Applications (O, Oral; D, Dermal; ET, Ear Tube; Oc, Ocular; N, Nasal; Oral and Nasal (No) and T, Topical); PAZ, Preferred Agroclimatic Zone (K, Kolla or Hot, WD, Woina Dega or temperate, D, Dega or cool) 


\begin{tabular}{|c|c|c|c|c|c|c|c|c|c|c|}
\hline No & Family Name & Botanical Name & $\begin{array}{l}\text { Vernacular } \\
\text { Name }\end{array}$ & $\mathrm{GH}$ & $\mathrm{Ha}$ & PU & $\begin{array}{l}\text { Ethnoveterinary } \\
\text { Use }\end{array}$ & $\begin{array}{l}\text { Traditional } \\
\text { usage }\end{array}$ & $\mathrm{Ra}$ & PAZ \\
\hline 57 & Lamiaceae & $\begin{array}{l}\text { Ocimum } \\
\text { basilicum }\end{array}$ & Ajuban & $\mathrm{H}$ & C & L & Bloating & $\begin{array}{l}\text { Fresh leaves } \\
\text { with the bulb of } \\
\text { Allium sativum } \\
\text { and salt } \\
\text { grained } \\
\text { together, mixed } \\
\text { with water and } \\
\text { given a single } \\
\text { litter of the } \\
\text { mixture for } \\
\text { cattle }\end{array}$ & 0 & $\mathrm{WD}, \mathrm{K}$ \\
\hline 58 & Lamiaceae & $\begin{array}{l}\text { Ocimum } \\
\text { lamiifolium } \\
\text { Benth }\end{array}$ & Damakase & S & WC & L & $\begin{array}{l}\text { Respiratory } \\
\text { infection }\end{array}$ & $\begin{array}{l}\text { Pounded } \\
\text { together with } \\
\text { water, filtered } \\
\text { and quarter of } \\
\text { litter is given to } \\
\text { cattle }\end{array}$ & $\mathrm{T}$ & $\begin{array}{l}\mathrm{K}, \mathrm{WD} \\
\mathrm{D}\end{array}$ \\
\hline 59 & Oleaceae & $\begin{array}{l}\text { Olea capensis } \\
\text { L.Subsp. } \\
\text { macrocarpa }\end{array}$ & Woyra & $\mathrm{T}$ & WC & $\mathrm{L}$ & Eye infection & $\begin{array}{l}\text { Leaves are } \\
\text { chewed and } \\
\text { applied to eye } \\
(1 \\
\text { teaspoon/dose) } \\
\text { for three days }\end{array}$ & Oc & $\begin{array}{l}\mathrm{K}, \mathrm{WD} \\
\mathrm{D}\end{array}$ \\
\hline 60 & Oleaceae & Olea europaea & Weyra & $\mathrm{T}$ & W & St & Eye disease & $\begin{array}{l}\text { Ground } \\
\text { together with } \\
\text { the leaves of } \\
\text { Jasminum } \\
\text { abyssinicum, } \\
\text { mixed with } \\
\text { water, and } \\
\text { applied three } \\
\text { drop on the } \\
\text { infection site } \\
\text { for five days }\end{array}$ & Oc & $D, W D$ \\
\hline 61 & Orobanchaceae & $\begin{array}{l}\text { Orobanche } \\
\text { ramose }\end{array}$ & $\begin{array}{l}\text { Ye gebe } \\
\text { shenkurte }\end{array}$ & $\mathrm{P}$ & W & s & Sun stroke & $\begin{array}{l}\text { Pounded, mixed } \\
\text { with little water } \\
\text { and creamed } \\
\text { the inflamed } \\
\text { part of equines }\end{array}$ & D & $\mathrm{K}$ \\
\hline 62 & Lamiaceae & $\begin{array}{l}\text { Otostegia } \\
\text { integrifolia }\end{array}$ & Tunjit & S & W & L & Stomach ache & $\begin{array}{l}\text { Leaves are } \\
\text { crushed well, } \\
\text { mixed with one } \\
\text { litter of water } \\
\text { and then given } \\
\text { a litter of the } \\
\text { blend for two } \\
\text { days to cattle }\end{array}$ & 0 & WD \\
\hline 63 & Arecaceae & $\begin{array}{l}\text { Phoenix } \\
\text { reclinata Jacq. }\end{array}$ & $\begin{array}{l}\text { Yehosaena } \\
\text { zaf }\end{array}$ & $\mathrm{T}$ & C & S & Eye disease & $\begin{array}{l}\text { Its leaf and } \\
\text { stem are } \\
\text { blended } \\
\text { together with } \\
\text { the leaf of } \\
\text { Premna } \\
\text { resinosa, and } \\
\text { applied on the } \\
\text { infected cattle } \\
\text { eye }\end{array}$ & Oc & $\mathrm{K}, \mathrm{WD}$ \\
\hline 64 & Phytolaccacaceae & $\begin{array}{l}\text { Phytolacca } \\
\text { dodecandra L. }\end{array}$ & Endod & S & W & $\mathrm{L}$ & Leech & $\begin{array}{l}\text { Fresh leaf is } \\
\text { crushed, mixed } \\
\text { with water and } \\
\text { then } 1 / 3 \text { of liter } \\
\text { is given for } \\
\text { three days }\end{array}$ & No & $\mathrm{K}, \mathrm{WD}, \mathrm{D}$ \\
\hline \multicolumn{11}{|c|}{$\begin{array}{l}\text { Note: GH, Growth Habits (T, Tree; H, Herb; S, Shrub; C, Climbers and P, Parasitic); Ha, Habitats (W, Wild; C, Cultivated and WC, Wild and } \\
\text { Cultivated); PU, Parts Used'(L, Leaves; Sd, Seed; B, Bark; F, Fruits; S, Shoot; St, Stem; R, Root; LX, Latex); RA, Routs of Applications (O, Oral } \\
\text { D, Dermal; ET, Ear Tube; Oc, Ocular; N, Nasal; Oral and Nasal (No) and T, Topical); PAZ, Preferred Agroclimatic Zone (K, Kolla or Hot, WD, } \\
\text { Woina Dega or temperate, D, Dega or cool) }\end{array}$} \\
\hline
\end{tabular}




\begin{tabular}{|c|c|c|c|c|c|c|c|c|c|c|}
\hline No & Family Name & Botanical Name & $\begin{array}{l}\text { Vernacular } \\
\text { Name }\end{array}$ & GH & $\mathrm{Ha}$ & PU & $\begin{array}{l}\text { Ethnoveterinary } \\
\text { Use }\end{array}$ & $\begin{array}{l}\text { Traditional } \\
\text { usage }\end{array}$ & $\mathrm{Ra}$ & PAZ \\
\hline & & & & & & & Eye disease & $\begin{array}{l}\text { Pounded and } \\
\text { mixed with } \\
\text { butter and } \\
\text { added on an } \\
\text { animal eye }\end{array}$ & Oc & \\
\hline 65 & Lamiaceae & $\begin{array}{l}\text { Premna } \\
\text { schimperi }\end{array}$ & Chocho & $S$ & W & $\mathrm{L}$ & Eye disease & $\begin{array}{l}\text { Pulverized, } \\
\text { mixed with little } \\
\text { water and } \\
\text { creamed to the } \\
\text { cattle's eye }\end{array}$ & Oc & K \\
\hline 66 & Rosaceae & $\begin{array}{l}\text { Prunus africana } \\
\text { (Hook.f.)Kalm. }\end{array}$ & Kok & $\mathrm{T}$ & C & B & Wound & $\begin{array}{l}\text { Powdered and } \\
\text { applied the } \\
\text { watery mixture } \\
\text { directly on } \\
\text { wound of } \\
\text { equines }\end{array}$ & $\mathrm{D}$ & WD, D \\
\hline 67 & Rosaceae & Prunus persica & Kok & S & C & $\mathrm{L}$ & Diarrhea & $\begin{array}{l}\text { Leaves are } \\
\text { crushed, mixed } \\
\text { with water and } \\
\text { given to the calf }\end{array}$ & 0 & $D, W D$ \\
\hline 68 & Rhamnaceae & $\begin{array}{l}\text { Rhamnus } \\
\text { prinoides L. } \\
\text { Herit }\end{array}$ & Gesho & S & $\mathrm{C}$ & $\mathrm{L}$ & $\begin{array}{l}\text { Sudden } \\
\text { disease }\end{array}$ & $\begin{array}{l}\text { Crushed the } \\
\text { leaves with } A \text {. } \\
\text { sativum and } L \text {. } \\
\text { sativum, mixed } \\
\text { together and } \\
\text { then given one } \\
\text { litter to the } \\
\text { cattle }\end{array}$ & 0 & $\begin{array}{l}\text { K, WD, } \\
\text { D }\end{array}$ \\
\hline 69 & Anacardiaceae & Rhus vulgaris & Embs & S & W & $\mathrm{R}$ & Diarrhea & $\begin{array}{l}\text { Its root with the } \\
\text { bulb of Allium } \\
\text { sativum are } \\
\text { grounded, } \\
\text { powdered, } \\
\text { mixed with } \\
\text { water and } \\
\text { allowed a litter } \\
\text { of the solution } \\
\text { to drunk }\end{array}$ & 0 & $D$ \\
\hline 70 & Euphorbiaceae & $\begin{array}{l}\text { Ricinus } \\
\text { communis }\end{array}$ & Gulo & $\mathrm{H}$ & WC & $\mathrm{F}$ & Ear ache & $\begin{array}{l}\text { Its fruit is } \\
\text { crushed and } \\
\text { applied three } \\
\text { drop of the fluid } \\
\text { in to ear tube of } \\
\text { the cattle }\end{array}$ & ET & $\begin{array}{l}\text { K, WD, } \\
\text { D }\end{array}$ \\
\hline 71 & Polygonaceae & $\begin{array}{l}\text { Rumex } \\
\text { nepalensis } \\
\text { Spreng }\end{array}$ & Tult & $\mathrm{H}$ & W & $\mathrm{R}$ & Bloating & $\begin{array}{l}\text { Roots are } \\
\text { pounded, mixed } \\
\text { with water and } \\
\text { half of a litter is } \\
\text { given twice for } \\
\text { three days }\end{array}$ & No & $D, W D$ \\
\hline
\end{tabular}

Note: GH, Growth Habits (T, Tree; H, Herb; S, Shrub; C, Climbers and P, Parasitic); Ha, Habitats (W, Wild; C, Cultivated and WC, Wild and Cultivated); PU, Parts Used (L, Leaves; Sd, Seed; B, Bark; F, Fruits; S, Shoot; St, Stem; R, Root; Lx, Latex); RA, Routs of Applications (O, Oral; D, Dermal; ET, Ear Tube; Oc, Ocular; N, Nasal; Oral and Nasal (No) and T, Topical); PAZ, Preferred Agroclimatic Zone (K, Kolla or Hot, WD, Woina Dega or temperate, D, Dega or cool) 


\begin{tabular}{|c|c|c|c|c|c|c|c|c|c|c|}
\hline No & Family Name & Botanical Name & $\begin{array}{l}\text { Vernacular } \\
\text { Name }\end{array}$ & $\mathrm{GH}$ & $\mathrm{Ha}$ & PU & $\begin{array}{l}\text { Ethnoveterinary } \\
\text { Use }\end{array}$ & $\begin{array}{l}\text { Traditional } \\
\text { usage }\end{array}$ & $\mathrm{Ra}$ & PAZ \\
\hline 72 & Polygonaceae & Rumex nervosus & Embuacho & $\mathrm{S}$ & W & $\mathrm{L}$ & $\begin{array}{l}\text { External } \\
\text { Parasite }\end{array}$ & $\begin{array}{l}\text { Powdered, } \\
\text { mixed with } \\
\text { water and then } \\
\text { wash the } \\
\text { affected body } \\
\text { in every } \\
\text { morning for at } \\
\text { least } 5 \text { days }\end{array}$ & $D$ & WD \\
\hline 73 & Rutaceae & $\begin{array}{l}\text { Ruta } \\
\text { chalepensis L. }\end{array}$ & Tenadam & $\mathrm{H}$ & $\mathrm{C}$ & $\mathrm{L}$ & $\begin{array}{l}\text { abdominal } \\
\text { pain }\end{array}$ & $\begin{array}{l}\text { Chopped the } \\
\text { leaves, soaked } \\
\text { with a litter of } \\
\text { water for two } \\
\text { days, filtered } \\
\text { and given a } \\
\text { single litter of } \\
\text { the solution to } \\
\text { cattle }\end{array}$ & 0 & $\begin{array}{l}\text { K, WD, } \\
\text { D }\end{array}$ \\
\hline 74 & Anacardiaceae & Schinus molle L. & $\begin{array}{l}\text { Qundo } \\
\text { berbere }\end{array}$ & $\mathrm{T}$ & WC & $\mathrm{L}$ & Eye disease & $\begin{array}{l}\text { Its leaf and } \\
\text { fruits are } \\
\text { squashed and } \\
\text { directly applied } \\
\text { on the infected } \\
\text { eye of cattle, } \\
\text { goat, and sheep } \\
\text { and equines } \\
\text { eye. }\end{array}$ & Oc & $\mathrm{K}$ \\
\hline 75 & Pedaliaceae & $\begin{array}{l}\text { Sesamum } \\
\text { orientale }\end{array}$ & Selit & $\mathrm{H}$ & $\mathrm{C}$ & $\mathrm{Sd}$ & $\begin{array}{l}\text { Sudden } \\
\text { Sickness }\end{array}$ & $\begin{array}{l}\text { Its seeds } \\
\text { grounded, } \\
\text { mixed with } \\
\text { water, and then } \\
\text { one litter of the } \\
\text { mixture is given } \\
\text { to the cattle }\end{array}$ & 0 & $\mathrm{~K}$ \\
\hline \multirow[t]{2}{*}{76} & Asteraceae & Solanecio gigas & $\begin{array}{l}\text { Shekoko } \\
\text { Gomen }\end{array}$ & $\mathrm{H}$ & W & $\mathrm{L}$ & Bloating & $\begin{array}{l}\text { Pounded and } \\
\text { given with } \\
\text { water }\end{array}$ & 0 & WD, K \\
\hline & & & & & & & $\begin{array}{l}\text { Sudden } \\
\text { sickness }\end{array}$ & $\begin{array}{l}\text { Leaves are } \\
\text { crushed, mixed } \\
\text { with water and } \\
\text { then half of a } \\
\text { litter is given for } \\
\text { two days }\end{array}$ & 0 & \\
\hline 77 & Solanaceae & $\begin{array}{l}\text { Solanum } \\
\text { anguivi }\end{array}$ & Zerchenby & $S$ & W & $\mathrm{R}$ & Bloating & to cattle & 0 & WD, K \\
\hline \multirow[t]{2}{*}{78} & Solanaceae & $\begin{array}{l}\text { Solanum } \\
\text { incanum L. }\end{array}$ & Embauy & $S$ & W & $\mathrm{F}$ & Leech & $\begin{array}{l}\text { Juice is } \\
\text { inserted in to } \\
\text { cattle's nasal }\end{array}$ & $\mathrm{N}$ & $\mathrm{K}$ \\
\hline & & & & & & $\mathrm{L}$ & Leech & $\begin{array}{l}\text { Fresh leaves } \\
\text { are crushed, } \\
\text { mixed with } \\
\text { water and } \\
\text { applied via oral } \\
\text { or nasal }\end{array}$ & No & \\
\hline 79 & Solonaceae & $\begin{array}{l}\text { Solanum } \\
\text { marginatum L.F }\end{array}$ & Geberembay & $S$ & W & $\mathrm{Sd}$ & Cough & $\begin{array}{l}\text { Seeds are } \\
\text { burned, and } \\
\text { immediately } \\
\text { allowed tar to } \\
\text { fumigate the } \\
\text { cattle and } \\
\text { equines }\end{array}$ & $\mathrm{N}$ & $\begin{array}{l}\text { K, WD, } \\
\text { D }\end{array}$ \\
\hline $\begin{array}{l}\text { Note } \\
\text { Culti } \\
\text { D, D } \\
\text { Woir }\end{array}$ & $\begin{array}{l}\text { HH, Growth Habi } \\
\text { ted); PU, Parts L } \\
\text { nal; ET, Ear Tube } \\
\text { Dega or temper }\end{array}$ & $\begin{array}{l}\text { ree; H, Herb; S, Sh } \\
\text {, Leaves; Sd, See } \\
\text { cular; N, Nasal; O } \\
\text { Dega or cool) }\end{array}$ & $\begin{array}{l}\text {; C, Climber } \\
\text { 3, Bark; F, Fry } \\
\text { and Nasal ( }\end{array}$ & $\begin{array}{l}\text { d P } \\
\text { S, S } \\
\text { an }\end{array}$ & $\begin{array}{l}\text { ras } \\
\text { ot; } \\
\text { To }\end{array}$ & $\begin{array}{l}\text { ); } \\
\text { Stel } \\
\text { al); }\end{array}$ & $\begin{array}{l}\text { Habitats (W, Wild } \\
\text { R, Root; Lx, Latex } \\
\text { Z, Preferred Agro }\end{array}$ & $\begin{array}{l}\text { Cultivated and } \\
\text { A, Routs of App } \\
\text { natic Zone (K, K }\end{array}$ & $\begin{array}{l}\text { Wilc } \\
\text { tion } \\
\text { or }\end{array}$ & $\begin{array}{l}\text { and } \\
\text { (O, Oral; } \\
\text { ot, WD, }\end{array}$ \\
\hline
\end{tabular}




\begin{tabular}{|c|c|c|c|c|c|c|c|c|c|c|}
\hline No & Family Name & Botanical Name & $\begin{array}{l}\text { Vernacular } \\
\text { Name }\end{array}$ & GH & $\mathrm{Ha}$ & PU & $\begin{array}{l}\text { Ethnoveterinary } \\
\text { Use }\end{array}$ & $\begin{array}{l}\text { Traditional } \\
\text { usage }\end{array}$ & $\mathrm{Ra}$ & PAZ \\
\hline & & & & & & $\mathrm{F}$ & Cough & $\begin{array}{l}\text { Squeezed the } \\
\text { fruit juice, } \\
\text { mixed with } \\
\text { goats milk and } \\
\text { provide via } \\
\text { nasal }\end{array}$ & $\mathrm{N}$ & \\
\hline & & & & & & & Eye disease & $\begin{array}{l}\text { Pounded, mixed } \\
\text { with the leaf } \\
\text { Phytolaca } \\
\text { dedecondra } \\
\text { and butter and } \\
\text { applied on the } \\
\text { eye }\end{array}$ & Oc & \\
\hline 80 & Solonaceae & Solanum nigrum & Tikur awit & $\mathrm{H}$ & W & L & Lung disease & $\begin{array}{l}\text { Pounded the } \\
\text { leaf, mixed with } \\
\text { water and given } \\
\text { to drink }\end{array}$ & 0 & WD, D \\
\hline 81 & Poaceae & $\begin{array}{l}\text { Sorghum bicolor } \\
\text { L. }\end{array}$ & Mashila & $\mathrm{H}$ & C & $\mathrm{Sd}$ & $\begin{array}{l}\text { Retained } \\
\text { placenta }\end{array}$ & $\begin{array}{l}\text { Dry seeds } \\
\text { mixed with salt } \\
\text { and water, and } \\
\text { a litter of it is } \\
\text { given to cattle. }\end{array}$ & 0 & K \\
\hline 82 & Menispermaceae & $\begin{array}{l}\text { Stephania } \\
\text { abyssinica }\end{array}$ & Chewchwit & $\mathrm{H}$ & W & $\mathrm{R}$ & Anthrax & $\begin{array}{l}\text { Crushed, mixed } \\
\text { with water and } \\
\text { then given to } \\
\text { cattle }\end{array}$ & 0 & $\mathrm{~K}, \mathrm{WD}$ \\
\hline 83 & Bignoniaceae & $\begin{array}{l}\text { Stereospermum } \\
\text { kunthianum } \\
\text { Cham }\end{array}$ & & $\mathrm{T}$ & W & $\mathrm{R}$ & Snake bite & $\begin{array}{l}\text { Powdered its } \\
\text { root with dried } \\
\text { leaf of } \\
\text { Calpurina } \\
\text { aurea, mixed } \\
\text { with water and } \\
\text { then given to } \\
\text { cattle }\end{array}$ & 0 & K \\
\hline 84 & Scrophulariacee & $\begin{array}{l}\text { Striga } \\
\text { hermonthica }\end{array}$ & Gelmit & $\mathrm{H}$ & W & St & Bloating & $\begin{array}{l}\text { Crushed the } \\
\text { stem, } \\
\text { powdered, } \\
\text { mixed with } \\
\text { water and half } \\
\text { a litter is given } \\
\text { to the cattle }\end{array}$ & 0 & $\mathrm{~K}, \mathrm{WD}$ \\
\hline 85 & Asteraceae & $\begin{array}{l}\text { Tarchonanthus } \\
\text { camphoratus } \mathrm{L} \text {. }\end{array}$ & & S & W & L & $\begin{array}{l}\text { Abdominal } \\
\text { disorders }\end{array}$ & $\begin{array}{l}\text { Leave is } \\
\text { crushed, } \\
\text { pounded and } \\
\text { mixed with } \\
\text { water, and then } \\
\text { a half litter of it } \\
\text { is given for } \\
\text { three days for } \\
\text { cattle, sheep, } \\
\text { goats and } \\
\text { equines }\end{array}$ & 0 & $\begin{array}{l}\text { K,WD, } \\
\text { D }\end{array}$ \\
\hline 86 & Euphorbiaceae & Tragia cinerea & Aleblabit & $\mathrm{H}$ & W & L & $\begin{array}{l}\text { Sudden } \\
\text { Disease }\end{array}$ & $\begin{array}{l}\text { Ground, } \\
\text { powdered and } \\
\text { mixed with } \\
\text { water, then } 1 / 3 \\
\text { of a litter is } \\
\text { given for four } \\
\text { subsequent } \\
\text { days for } \\
\text { livestock }\end{array}$ & 0 & K \\
\hline
\end{tabular}

Note: GH, Growth Habits (T, Tree; H, Herb; S, Shrub; C, Climbers and P, Parasitic); Ha, Habitats (W, Wild; C, Cultivated and WC, Wild and Cultivated); PU, Parts Used (L, Leaves; Sd, Seed; B, Bark; F, Fruits; S, Shoot; St, Stem; R, Root; Lx, Latex); RA, Routs of Applications (O, Oral; D, Dermal; ET, Ear Tube; Oc, Ocular; N, Nasal; Oral and Nasal (No) and T, Topical); PAZ, Preferred Agroclimatic Zone (K, Kolla or Hot, WD, Woina Dega or temperate, D, Dega or cool) 


\begin{tabular}{|c|c|c|c|c|c|c|c|c|c|c|}
\hline No & Family Name & Botanical Name & $\begin{array}{l}\text { Vernacular } \\
\text { Name }\end{array}$ & $\mathrm{GH}$ & $\mathrm{Ha}$ & PU & $\begin{array}{l}\text { Ethnoveterinary } \\
\text { Use }\end{array}$ & $\begin{array}{l}\text { Traditional } \\
\text { usage }\end{array}$ & $\mathbf{R a}$ & PAZ \\
\hline 87 & Fabaceae & $\begin{array}{l}\text { Trigonella } \\
\text { foenumgraecum } \\
\text { L. }\end{array}$ & Abish & $\mathrm{H}$ & C & $\mathrm{Sd}$ & Eye infection & $\begin{array}{l}\text { Dry seed are } \\
\text { grounded into } \\
\text { powder and } \\
\text { then added to } \\
\text { the eye of } \\
\text { cattle, goats, } \\
\text { sheep, donkey }\end{array}$ & Oc & WD, D \\
\hline 88 & Utricaceae & $\begin{array}{l}\text { Urera } \\
\text { hypselodendron }\end{array}$ & Lankusso & $\mathrm{C}$ & W & St & Anthrax & $\begin{array}{l}\text { Crushed, mixed } \\
\text { with water and } \\
\text { then one third } \\
\text { of a litter is } \\
\text { given to cattle }\end{array}$ & 0 & K \\
\hline 89 & Utricaceae & Urtica simensis & Sama & $\mathrm{H}$ & W & $\mathrm{R}$ & $\begin{array}{l}\text { Sudden } \\
\text { Sickness }\end{array}$ & $\begin{array}{l}\text { Its root alone or } \\
\text { with leaves are } \\
\text { crushed } \\
\text { together, mixed } \\
\text { with water and } \\
\text { half of a litter is } \\
\text { given for two } \\
\text { days }\end{array}$ & 0 & D \\
\hline 90 & Scrophulariaceae & $\begin{array}{l}\text { Verbasum } \\
\text { sinaticum }\end{array}$ & Ketetina & $\mathrm{H}$ & W & $\mathrm{R}$ & Evil eye & $\begin{array}{l}\text { Pounded, } \\
\text { boiled, allowed } \\
\text { to cool down } \\
\text { and then half of } \\
\text { a litter is given } \\
\text { for three days } \\
\text { in every } \\
\text { morning }\end{array}$ & No & $K, W D$ \\
\hline 91 & Verbenaceae & $\begin{array}{l}\text { Verbena } \\
\text { officinalis } \mathrm{L}\end{array}$ & Atuch & $\mathrm{H}$ & W & $\mathrm{L}$ & Snake bite & $\begin{array}{l}\text { Its squeezed } \\
\text { fluid is creamed } \\
\text { on the infected } \\
\text { site }\end{array}$ & $\mathrm{D}$ & D \\
\hline 92 & Asteraceae & $\begin{array}{l}\text { Vernonia } \\
\text { amygdalina } \\
\text { Delile. }\end{array}$ & Grawa & $\mathrm{T}$ & W & $\mathrm{Sd}$ & $\begin{array}{l}\text { Abdominal } \\
\text { pain }\end{array}$ & $\begin{array}{l}\text { Crushed seed } \\
\text { mixed with } \\
\text { water, filtered } \\
\text { and half of it is } \\
\text { given to the } \\
\text { livestock }\end{array}$ & No & WD \\
\hline 93 & Asteraceae & $\begin{array}{l}\text { Vernonia } \\
\text { auriculifera } \\
\text { Hiern }\end{array}$ & & S & W & L & $\begin{array}{l}\text { Internal } \\
\text { parasite }\end{array}$ & $\begin{array}{l}\text { Pounded } \\
\text { together; mixed } \\
\text { with } 1 \text { litter of } \\
\text { water and given } \\
\text { to livestock } \\
\text { once }\end{array}$ & 0 & K \\
\hline \multirow[t]{2}{*}{94} & Asteraceae & Zehneria scabra & Heregresa & $\mathrm{C}$ & W & St & Wound & $\begin{array}{l}\text { Rubbed and } \\
\text { creamed on the } \\
\text { wound site of } \\
\text { the livestock }\end{array}$ & $\mathrm{D}$ & WD, D \\
\hline & & & & & & $\mathrm{R}$ & Thinning & $\begin{array}{l}\text { Fresh root } \\
\text { crushed, mixed } \\
\text { with water, and } \\
\text { half of litter is } \\
\text { given for two } \\
\text { days to the } \\
\text { cattle }\end{array}$ & 0 & \\
\hline
\end{tabular}

Note: GH, Growth Habits (T, Tree; H, Herb; S, Shrub; C, Climbers and P, Parasitic); Ha, Habitats (W, Wild; C, Cultivated and WC, Wild and Cultivated); PU, Parts Used (L, Leaves; Sd, Seed; B, Bark; F, Fruits; S, Shoot; St, Stem; R, Root; Lx, Latex); RA, Routs of Applications (O, Oral; D, Dermal; ET, Ear Tube; Oc, Ocular; N, Nasal; Oral and Nasal (No) and T, Topical); PAZ, Preferred Agroclimatic Zone (K, Kolla or Hot, WD, Woina Dega or temperate, D, Dega or cool) 


\begin{tabular}{|c|c|c|c|c|c|c|c|c|c|c|}
\hline No & Family Name & Botanical Name & $\begin{array}{l}\text { Vernacular } \\
\text { Name }\end{array}$ & $\mathrm{GH}$ & $\mathrm{Ha}$ & PU & $\begin{array}{l}\text { Ethnoveterinary } \\
\text { Use }\end{array}$ & $\begin{array}{l}\text { Traditional } \\
\text { usage }\end{array}$ & $\mathrm{Ra}$ & PAZ \\
\hline 95 & Zingiberaceae & $\begin{array}{l}\text { Zingibar } \\
\text { officinale }\end{array}$ & Jingibl & $\mathrm{H}$ & C & $\mathrm{L}$ & Eye infection & $\begin{array}{l}\text { Pounded, mixed } \\
\text { with water and } \\
\text { then three to } \\
\text { five drops of } \\
\text { the fusion is } \\
\text { given to the } \\
\text { cattle }\end{array}$ & $\mathrm{T}$ & $\mathrm{K}$ \\
\hline \multicolumn{11}{|c|}{$\begin{array}{l}\text { Note: GH, Growth Habits (T, Tree; H, Herb; S, Shrub; C, Climbers and P, Parasitic); Ha, Habitats (W, Wild; C, Cultivated and WC, Wild and } \\
\text { Cultivated); PU, Parts Used (L, Leaves; Sd, Seed; B, Bark; F, Fruits; S, Shoot; St, Stem; R, Root; LX, Latex); RA, Routs of Applications (O, Ora } \\
\text { D, Dermal; ET, Ear Tube; Oc, Ocular; N, Nasal; Oral and Nasal (No) and T, Topical); PAZ, Preferred Agroclimatic Zone (K, Kolla or Hot, WD, } \\
\text { Woina Dega or temperate, D, Dega or cool) }\end{array}$} \\
\hline
\end{tabular}

Table 4

ANOVA on the most common medicinal plant species $(n=20)$ used as a potential remedies for livestock diseases in the three agroclimatic zonings

\begin{tabular}{|lllll|}
\hline Variable & Source & DF & F & P \\
\hline Number of Species & Agroclimate & 2 & 82.33 & 0.00 \\
\hline Numbers of Families & Agroclimate & 2 & 11.69 & 0.179 \\
\hline Use value & Agroclimate & 2 & 5.41 & 0.007 \\
\hline Fidelity Level & Agroclimate & 2 & 3.95 & 0.025 \\
\hline Relative Frequency of Citations & Agroclimate & 2 & 3.55 & 0.035 \\
\hline DF, Degree of Freedom; F, Fisher test; P, Probability of Significance \\
\hline
\end{tabular}

\section{Ethnoveterinarical approach for the treatments of livestock ailments}

The highest livestock remedies of using plants as interventions in the three agroclimatic zones were for the treatment of eye disease (13taxa; 11.82\%), bloating (10taxa; 9.1\%), wound (8taxa; 7.27\%), anthrax (7taxa;6.36 \%), diarrhea/ bloody diarrhea (6taxa; 5.45\%); cough (4taxa; 3.64\%); abdominal disorder (3taxa; 2.73\%), external parasites (3taxa; $2.73 \%$ ), respiratory infections (2taxa; 1.82 ) whilst lung disease and heart disease have the least $(1 ; 0.91 \%)$ number of plant species cited as being used for each disease treatment. In the same way, the Asteraceae was found to be the most preferred with eleven therapeutic values of veterinary diseases followed by the Fabaceae (10), Euphorbiaceae (7), Solanaceae (6) and Brassicaceae treated four veterinary diseases (Table 3). In terms of medicinal species, Erythrina brucei, Inula confertiflora, Solanum marginatum, Zehneria scabra, Datura stramonium, Croton macrostachyus and Cucumis ficifolius were the most frequently documented species used to treat eye infection, bloating, wound and bloody diarrhea (Table 3). The leaves 41 (39.05\%) were identified as the most often used plant part for the formulation of traditional remedies and the next important medicinal plants parts for the treatment of livestock ailments wereroots28 (26.66\%), seeds 11 (10.48\%), barks 7 (6.67\%) and fruits 6 (5.71\%) (Fig. 4).In addition, the local people in the surveyed communities prepared livestock remedies from the natural and plant products by employing varied techniques. Thus the most frequently applied recipe was crushing and pounding the plant part (s) and administered via oral $59(54.63 \%)$, dermal 24(22.22\%), ocular 9 (8.33\%), oral and nasal 7 (6.5\%), nasal 4 (3.70\%), topical $3(2.77 \%)$ and ear tube $2(1.85 \%)$ (Fig. 4 ).

\section{Values of ethnoveterinary indices across the surveyed agroclimates}

The present study revealed that there was a significant difference $(F=5.41, P<0.01)$ in the use value (UV) of medicinal plants to treat livestock disease among agroclimatic zones (Table 4), which ranged from 0.05 to 0.85 . The highest use values were obtained for Datura stramonium (UV = 0.85), Brassica nigra (UV = 0.75) and Albizia schimperiana ( $U V=0.77)$ whilst the lower values were found to be in Ricinus communis (UV = 0.27), Argemone mexicana (UV = 0.15) and Cucurbita pepo $(U V=0.05)$ plant species of the Habru, Gubalafto and Meket districts respectively (Table 5). In this study, we also found considerable differences in $F L(F=3.95, P<0.05$ and $R F C s(F=3.55, P<0.05)$ among the studied agroclimatic zones (Table 4). Thus eleven, six and five potential traditional plant remedies for livestock diseases having greater FL values (ranges from 50-100\%) were identified in the hot (Habru; Kolla), temperate (Gubalafto; Woina Dega) and cool (Meket; Dega) agroclimatic zones, respectively. Correspondingly, D. stramonium was found the highest FL ( $90.4 \%$ ) in hot (Kolla) agroclimate whist C. macrostachyus (75\%) and B. nigra (73.9 \%) were recorded as the highest FL species in temperate (Woina Dega) and cool (Dega) agroclimates, respectively (Table 5). In terms of RFCs, D. stramonium (0.8), S. marginatum (0.57) and $O$. capensis (0.55) medicinal plant species were highest RFCs for the treatments of livestock diseases but $S$. marginatum $(0.07), R$. prinoides $(0.05)$ and $C$. ficifolius $(0.02)$ are 
observed lower RFCs values in Habru, Gubalafto and Meket districts, respectively (Table 5). Furthermore, Informant Consensus Factor (ICF) results have shown a high degree of agreement for bloating (0.87), bloody diarrhea (0.85), eye infection (0.84), wound (0.84) and anthrax (0.81) livestock ailments whilst relatively lower for sudden sickness, abdominal disorder and evil eye (0.5 each) (Table 6), whereby the highest plant use citation was for eye infection (74) followed by bloating (69) and wound (45) ailments (Table 6).

Table 5. The quantitative ethnoveterinarical indices of the most common occurring medicinal plant species $(n=20)$ in each of surveyed

$(\mathrm{n}=40)$ agroclimatic conditions at Kolla (hot agroclimate zone), Woina Dega (temperate agroclimate zone) and Dega (cool agroclimate zone)

\begin{tabular}{|c|c|c|c|c|c|c|c|c|c|c|}
\hline \multirow[t]{2}{*}{ Botanical Name } & \multirow[t]{2}{*}{ Therapeutic value } & \multicolumn{3}{|c|}{ KoKolla } & \multicolumn{3}{|c|}{ Woina Dega } & \multicolumn{3}{|c|}{ Dega } \\
\hline & & UV & FL & RFCs & UV & FL & RFCs & UV & FL & RFCs \\
\hline Albizia schimperiana & Blackleg & 0.67 & 25.9 & 0.12 & 0.20 & 32.1 & 0.12 & 0.77 & 25.0 & 0.22 \\
\hline Argemone mexicanal & Devil disease & 0.40 & 42.8 & 0.47 & 0.15 & 20.0 & 0.07 & 0.25 & 58.3 & 0.20 \\
\hline Brassica carinata & Stomachache & 0.70 & 86.4 & 0.70 & 0.40 & 30.8 & 0.42 & 0.45 & 32.1 & 0.25 \\
\hline Brassica nigra & Stomach worm & 0.72 & 54.5 & 0.72 & 0.75 & 36.0 & 0.47 & 0.70 & 73.9 & 0.32 \\
\hline Bridella micrantha & Expel placenta & 0.60 & 35.7 & 0.20 & 0.52 & 37.5 & 0.47 & 0.50 & 36.4 & 0.47 \\
\hline Cordia africana & Ear mite & 0.35 & 26.1 & 0.22 & 0.67 & 32.0 & 0.15 & 0.52 & 23.8 & 0.15 \\
\hline Croton macrostachyus & Ringworms; Wound & 0.47 & 44.0 & 0.30 & 0.22 & 75.0 & 0.20 & 0.27 & 13.6 & 0.10 \\
\hline Cucumis ficifolius & $\begin{array}{l}\text { Bloody Diarrhea, } \\
\text { Bloating }\end{array}$ & 0.57 & 60.0 & 0.75 & 0.22 & 73.9 & 0.37 & 0.27 & 28.0 & 0.02 \\
\hline Cucurbita pepo & Expel Placenta & 0.50 & 26.1 & 0.40 & 0.15 & 18.2 & 0.17 & 0.05 & 15.4 & 0.52 \\
\hline Datura stramonium & Wound & 0.85 & 90.4 & 0.80 & 0.42 & 33.3 & 0.45 & 0.55 & 8.3 & 0.42 \\
\hline Fagropsis angoleusis & Respiratory disease & 0.55 & 53.8 & 0.42 & 0.67 & 58.3 & 0.12 & 0.42 & 60.9 & 0.10 \\
\hline Lepidium sativum & Diarrhea & 0.82 & 57.1 & 0.32 & 0.52 & 73.9 & 0.57 & 0.20 & 36.4 & 0.40 \\
\hline Ocimum lamiifolium & $\begin{array}{l}\text { Respiratory } \\
\text { infestation }\end{array}$ & 0.32 & 73.9 & 0.22 & 0.50 & 52.0 & 0.45 & 0.47 & 48.0 & 0.10 \\
\hline Olea capensis & Eye infection & 0.47 & 66.7 & 0.20 & 0.27 & 35.7 & 0.15 & 0.12 & 35.7 & 0.55 \\
\hline Phytolacca dodecandra & Eye disease; Leech & 0.67 & 34.6 & 0.35 & 0.45 & 16.7 & 0.17 & 0.10 & 66.7 & 0.05 \\
\hline Rhamnus prinoides & Sudden disease & 0.30 & 33.3 & 0.37 & 0.45 & 21.7 & 0.05 & 0.27 & 20.0 & 0.07 \\
\hline Ricinus communis & Ear infection & 0.27 & 46.1 & 0.40 & 0.20 & 50.0 & 0.10 & 0.37 & 30.0 & 0.12 \\
\hline Ruta chalepensis & Abdominal pain & 0.45 & 50.0 & 0.45 & 0.45 & 23.1 & 0.22 & 0.17 & 15.4 & 0.52 \\
\hline Solanum marginatu & Eye disease; cough & 0.6 & 69.6 & 0.07 & 0.32 & 24.1 & 0.57 & 0.15 & 68.2 & 0.15 \\
\hline Tarchonanthus camphoratus & Abdominal disorders & 0.35 & 60.0 & 0.27 & 0.45 & 27.6 & 0.10 & 0.32 & 16.0 & 0.07 \\
\hline
\end{tabular}

UV, Use Value; FL, Fidelity Level; RFCs, Relative Frequency of Citations

Table 6. Informant Consensus factor for the treatment of different livestock diseases in the tree agroclimatic zonation $(\mathrm{n}=120)$

\begin{tabular}{lccc}
\hline Types of Diseases & Nt & Nur & ICF \\
\hline Abdominal pain/ disorder & 3 & 5 & 0.5 \\
Anthrax & 7 & 33 & 0.81 \\
Eye Disease/ infection & 13 & 74 & 0.84 \\
Bloating & 10 & 69 & 0.87 \\
Bone broken/ Fracture & 3 & 7 & 0.67 \\
Cough & 4 & 16 & 0.80 \\
Devil disease/ Evil Eye & 2 & 3 & 0.5 \\
Diarrhea/ Bloody Diarrhea & 6 & 35 & 0.85 \\
Expel placenta & 3 & 9 & 0.75
\end{tabular}




\begin{tabular}{lccc} 
External parasite & 5 & 14 & 0.69 \\
Internal parasite & 3 & 10 & 0.78 \\
Stomachache & 3 & 7 & 0.67 \\
Sudden sickness & 4 & 7 & 0.5 \\
Thinning disease & 2 & 3 & 0.5 \\
Wound & 8 & 45 & 0.84 \\
\hline
\end{tabular}

ICF, Informant Consensus Factor; Nt, number of taxa; Nur, number of use reports

\section{Discussion}

Ethiopia hosts a large diversity of plant species [30], coupled with varied types of traditional plant based medicine and cultural heritage stemming from the treatments of livestock ailments $[1,11,19,24]$. More than $80 \%$ of the rural communities in Ethiopia use these plant remedies for livestock healthcare systems $[1,40]$. In this study, the majority $(77.5 \%)$ of the respondents were found to be using ethnoveterinary plants for treatments of their livestock ailments. The cross tabulated chi square confirms that a considerable association in medicinal plants citation among sex and age categories whilst there was no significant association with the educational status (Fig. 2). Irrespective of the association, males, elders and participants with no formal education enumerated relatively greater numbers of ethnoveterinary plants and this could be ascribed to these informants as having more experience to the plants and lores found in the localities. Similarly, Kidane et al. [13], Yirga et al. [20], Estomba et al. [41], Yineger et al. [42], Yigezu et al. [43] have reported that medicinal plant knowledge and species citation increase with age and in academic illiterate people, while the ancient knowledge is decreasing in the young generations. In the present study a total of 95 medicinal plant species and 44 families were found to treat 45 livestock ailments in the surveyed agroclimatic zones (Table 3). This is probably an indication of the study districts are rich in ethnoveterinary plant species compared to other research reports in neighboring areas. For instance, Assefa and Bahiru [23] and Yigezu et al. [43] have reported 53 and 74 species belonging to 31 families for treatment of 22 livestock ailments in Jimma zone and Abergelle, Sekota and Lalibela districts of Ethiopia. In other similar studies in Ethiopia by Luleka et al. [12], Kidane et al. [13], Yirga et al. [20], Feyera et al. [22] have documented 51, 46, 24 and 49 ethnoveterinary plant species to treat animal diseases, respectively.

Among 44 botanical families used to treat livestock diseases in our study, Asteraceae has the highest record (10) of species, followed by Fabaceae (9), Euphorbiaceae (6) and Solanaceae (6) (Fig.

3). In fact, the Asteraceae, Fabaceae, Lamiaceae and Solanaceae are large, mostly cosmopolitan families that are known to be medicinal values worldwide because of being rich in essential oils and other secondary metabolites [44]. The findings were in agreement with previous studies reported in Ethiopia by Luleka et al. [12], Yigezu et al. [43], Yineger et al. [45], Mesfin et al. [46] and in other countries by Tariq et al. [4] and Khan et al. [47] in which Asteraceae was the commonly used plant family by traditional healers for livestock diseases remedy. However, in this study we also found that a significant difference in the ethnoveterinary species $(P<0.01)$ across agroclimatic zones (Table 4$)$, in which relatively the highest numbers of species were found in hot (Kolla) agroclimatic zones followed by temperate and cool agroclimatic zones. This could be due to the fact that in hot area disease prevalence is very high and hence the local communities are familiar and relied on varied types of medicinal plants to treat their livestock ailments. Similar results were reported in lowlands (hot) of Konta (southern Ethiopia) that came up with 120 plant species for medicinal purposes [48]. In contrast, Khan et al. [2] noted that the diversity of ethnoveterinary plant species decreased with decreasing elevation from high altitude (cool) to plain area. As far as the usage across growth habits and habitats, herbs were the most commonly used growth forms for the treatments of livestock ailments (Fig. 4), which were widely growing in the wild habitats (Fig. 4). This greater reliance on herbs in livestock remedies might be due to the presence of potent chemicals of high curative efficiency but needs further phytochemical screening to validate the local knowledge. Similar studies on the local communities' use of herbs for the treatments of livestock ailments were reported by Khan et al. [2], Tariq et al. [4], Hassen et al. [49]. In terms of plant parts, leaves were the most frequently used part for livestock remedy formulation (Fig. 4), which was prepared mostly by crushing and pounding, mixed with water as vehicles for application via oral followed by dermal and ocular routes. Studies conducted by Tariq et al. [4], Feyera et al. [22], Hunde et al. [40], Hassen et al. [49], showed that leaves are the most considerable part used for preparation of livestock remedies. The present study is also in lines with the findings of Feyera et al. [22] and Eshetu et al. [50], who asserted that oral and dermal are the main routes of administration for livestock disease remedies. The majority of the ethnoveterinary plants reported are utilized to treat eye infection, followed by bloating and wound while a single medicinal species (Solanum nigrum) was cited for the treatment of lung livestock diseases. Also Assefa and Bahiru [23] in the adjacent agroclimatic zone to Gubalafto and Meket described that pasteurellosis and wound are the most frequently cited animal diseases. However, Kidane et al. [13] and Yineger et al. [45], reported blackleg followed by anthrax diseases seems to affect most frequently the cattle. The dissimilarity in the kind of livestock diseases could be ascribed to the variation in agroclimatic zonings. Medicinal plants with high informants report to a particular attribute always also have higher UV value and vice versa [51]. In this study considerable difference $(P<0.01)$ was observed in UV among the studied agroclimatic zone $($ Table 5$)$.

Page 22/29 
Three medicinal plant species commonly found in the three agroclimatic zones, Datura stramonium, Brassica nigra and Albizia schimperiana, were registered with higher UV values in hot, temperate and cool agroclimatic zones, respectively (Table 5).This implies that the species with greater UV are indispensable for the treatment of numbers of livestock diseases compared to the species with lower UV values. According to, Martin [38] and Trotter and Logan [51], plants with some repetitive manner are likely to be biologically active. In the same ways of considerable difference in FL and RFCs could be ascribed to the relative abundances of the ethnoveterinary plant species in the study provinces. Accordingly, the Datura stramonium, Croton macrostachyus and Brassica nigra were revealed higher FL values which are greater than 50 \% (Table 5) and in terms of RFCs, the Cucumis ficifolius, Solanum marginatum and Olea capensis found to be higher values in hot, temperate and cool climatic zonings, respectively (Table 5). The highest agreements (ICF $=0.87$ ) in using ten taxa of the 68 reported events was observed to cure bloating (Table 6) and this might indicate the ailment is common to the surveyed agroclimatic zones and the ethnoveterinary plants found to be conventionally effective in treating the ailment. This agrees with Ahmed and Murtaza [9], Aziz et al. [10], Luleka et al. [12], who observed that a high ICF value is allied to a few target plant species with high use reports in in treating a specific disease category and for screening bioactive compounds. In general the UV, FL (\%), RFCs and ICF values vary depending on locality, nature of vegetation and geo-climate $[47,51]$ and therefore their higher medicinal citations for a particular livestock disease treatment, for example, as observed in hot agroclimatic zone, could be ascribed to higher disease prevalence in this area which probably boosts the awareness of the traditional healers to formulate plant remedies for their livestock diseases than the witchdoctors in temperate and cool climatic zones.

\section{Conclusion}

Ethnoveterinary lore is becoming even more vital to maintain the animal healthcare system, productivity and sustainability of the people mainly in the area where modern veterinary clinics and experts are inaccessible. This explorative study exhibited the values of medicinal plants used by the local people in the three surveyed agroclimatic zonation (hot, temperate and cool) to treat their livestock ailments. In this survey, 95 medicinal plant species distributed across 44 families are documented against 45 livestock ailments, in which the traditional medicinal lore and practices have been orally transmitted from generation to generation. Datura stramonium, Erythrina brucei, Inula confertiflora, Solanum marginatum, Zehneria scabra, Croton macrostachyus and Cucumis ficifolius were the most widely used plant species for the treatments of most prevalent livestock diseases such as eye disease, bloating, and wound. The herbs and leaves were the most frequently used medicinal growth forms and parts for the formulation of traditional remedies which mostly are applied via oral route of administration. This study also showed that relatively greater ethnoveterinary plant species distribution was observed in hot agroclimatic zones and this could correspond to the high prevalence of diseases in the area. In addition, considerable difference in the UV, RFCs and FL were observed among the agroclimatic zonation and thus the ethnoveterinary plant species reported with higher UV, FL, IFC and RFCs values should be used for additional investigation and screening of the potential bioactive compounds for the synthesis of modern pharmaceutical products. In broad-spectrum, the surveyed districts are rich in ethnoveterinary plant resources compared to other research findings and it's therefore essential to conduct studies on the sustainable management and conservation of these plant genetic resources.

\section{Declarations}

\section{Competing interests}

The Authors of this manuscript have no conflicts of interest to declare

\section{Funding}

No funding was received for this research.

\section{Availability of data and materials}

All data are presented in this article

\section{Ethics approval and consent to participate}

Not applicable.

\section{Consent for publication}

Not applicable.

\section{Authors' contributions}


Ahmed Hassen and Meseret Muche: involved in designing, data collection, analysis, interpretations, and writing of the manuscript. Muthama Muasya and Berhanu Aberha: participated in manuscript organization and grammar editors. Both authors read and approved the final manuscript.

\section{Acknowledgements}

The authors are grateful to the traditional practitioners and local communities in the study districts who have provided us their valuable medicinal lore and practices and the anonymous reviewers' of ethnobotanists and veterinary science experts in Woldia University for providing useful comments and suggestions.

\section{References}

1. FAO. Livestock, health, livelihoods and the environment in Ethiopia: An integrated analysis, Rome; 2019.p.108.

2. Khan K, Rahman UI, Calixto SE, Ali N, ljaz F. Ethnoveterinary therapeutic practices and conservation status of the medicinal flora of Chamla valley, Khyber Pakhtunkhwa, Pakistan. Front Vet Sci. 2019;6:1-10.

3. Van der Merwe D, Swan GE, Botha CJ. Use of ethnoveterinary medicinal plants in cattle by Setswana speaking people in the Madikwe area of the North West Province of South Africa. J S Afr Vet Assoc. 2001;72:189-96.

4. Tariq A, Mussarat S, Adnan M, AbdElsalam MN, Ullah R, Khan AL. Ethnoveterinary study of medicinal plants in a tribal society of Sulaiman range. Sci. World J. 2014; 2014: 1-10.

5. Çağlar CS, Aslım G, Yaşar A. An ethnoveterinary study on plants used in the treatment of dermatological diseases in Central Anatolia, Turkey. J of Complement Med Res. 2018;8:71-84.

6. McCorkle CM. An introduction to ethnoveterinary research and development. J Ethnobiol. 1986;6:129-49.

7. Muhammad G, Khan ZM, Hussain HM, Iqbal Z, Iqbal M, Athar M. Ethnoveterinary practices of owners of pneumatic-cart pulling camels in Faisalabad City (Pakistan). J Ethnopharmacol. 2005;97:241-6.

8. Wanzala W, Zessin KH, Kyule NM, Baumann MP, Mathia E, Hassanali A. Ethnoveterinary medicine: a critical review of its evolution, perception, understanding and the way forward. Livest Res Rural Dev. 2005;17:1-19.

9. Ahmed MJ, Murtaza G. A study of medicinal plants used as ethnoveterinary: Harnessing potential phytotherapy in Bheri, District Muzaffarabad (Pakistan). J Ethnopharmacol. 2015;159:209-14.

10. Aziz MA, Khan AH, Pieroni A. Ethnoveterinary plants of Pakistan: a review. J Ethnobiol Ethnomed. 2020;16:1-18.

11. Mesfine T, Lemma M. The role of traditional veterinary herbal medicine and its constraints in the animal health care system in Ethiopia. In: Zewdu M, Demissie A, editors. Conservation and sustainable use of medicinal plants in Ethiopia. Institute of Biodiversity Conservation and Research, Addis Ababa, Ethiopia; 2001. p. 22-28.

12. Lulekal E, Asfaw Z, Kelbessa E, Van Damme P. Ethnoveterinary plants of Ankober District, North Shewa Zone, Amhara Region, Ethiopia. J Ethnobiol Ethnomedicine. 2014;10:3-19.

13. Kidane B, Van der Maesen LJG, Van Andel T, Asfaw Z. Ethnoveterinary medicinal plants used by the Maale and Ari ethnic communities in southern Ethiopia. J Ethnopharmacol. 2014;153:274-82.

14. Mayer M, Vogl CR, Amorena M, Hamburger M, Walkenhorst M. Treatment of organic livestock with medicinal plants: A systematic review of European ethnoveterinary research. Forsch Komplementmed. 2014;21:375-86.

15. Bartha SG, Quave CL, Balogh L, Papp N. Ethnoveterinary practices of Covasna County, Transylvania. Romania J Ethnobiol Ethnomed. 2015;11:2-22.

16. Mayer M, Zbinden M, Vogl RC, Ivemeyer S, Meier B, Amorena M, Maeschli A, Hamburger M, Walkenhorst M. Swiss ethnoveterinary knowledge on medicinal plants - a within-country comparison of Italian speaking regions with north-western German speaking regions. J Ethnobiol Ethnomed. 2017;13:2-23.

17. Matekaire T, Bwakura TM. Ethnoveterinary medicine: a potential alternative to orthodox animals health delivery in Zimbabwe. Intern J Appl Res Vet Med. 2004;2:269-73.

18. Musa MT, Eisa MZM, Ei-Sanousi EM, Wahab AB, Perrett L. Brucellosis in Camels (Camelus dromedarius) in Darfur, Western Sudan. J Comp Pathol. 2008;138:151-5.

19. Lulekal E, Kelbessa E, Bekele T, Yineger H. An ethnobotanical study of medicinal plants in Mana Angetu district, southeastern Ethiopia. J Ethnobiol Ethnomedicine. 2008;4:1-10.

20. Yirga G, Teferi M, Brhane G, Amare S. Plants used in ethnoveterinary practices in Medebay-Zana District, Northern Ethiopia. J Med Plants Res. 2012;6:433-8. 
21. Giday M, Teklehaymanot T. Ethnobotanical study of plants used in management of livestock health problems by Afar people of Ada'ar District, Afar Regional State, Ethiopia. J Ethnobiol Ethnomed. 2013;9:1-10.

22. Feyera T, Mekonnen E, Urga WB, Assefa S. Botanical ethnoveterinary therapies used by agro-pastoralists of Fafan zone, Eastern Ethiopia. BMC Vet Res. 2017;13:2-11.

23. Assefa A, Bahirua A. Ethnoveterinary botanical survey of medicinal plants in Abergelle, Sekota and Lalibela districts of Amhara region, Northern Ethiopia. J Ethnopharmacol. 2018;213:340-9.

24. Behnke R, Metaferia F. The contribution of livestock to the Ethiopian economy- Part II.I GAD livestock policy initiative working paper No. $02-11 ; 2011$.

25. CSA. Report on livestock and livestock characteristics (private peasant holdings), agricultural sample survey: vol II, statistical bulletin 585 Addis Ababa; 2017.

26. CSA. Agricultural sample survey statistical agency Federal Democratic Republic of Ethiopia: Central Statistics Agency Addis Ababa; 2011.

27. MOA. Ethiopian animal health year book 2011. Animal and Plant Health Regulatory Directorate; 2012. p. 72.

28. Ashenafi FB. Livestock disease management and food safety brief. In: Feed the Future Innovation Lab for Livestock Systems, 2016. p. 1-9.

29. North Wollo Agricultural and Rural Development (NWARD) office report. Annual livestock population reports (unpublished), Woldia, North Wollo, Ethiopia; 2019.

30. Bekele TA. Useful trees of Ethiopia: identification, propagation and management in 17 agro ecological zones, RELMA in ICRAF Project, Nairobi; 2007.p. 552.

31. Friis I, Demissew S, Van-Bruegel P. Atlas of the potential vegetation of Ethiopia. Copenhagen: Royal Danish Academy of Science and Letters; 2010.

32. Amhara Regional Kombolcha Weather Forecast (ARKWF). Database for meteorological data source (2009-2018/9 G.C) of North Wollo, Ethiopia; 2019.

33. Hedberg I, Edwards S. Flora of Ethiopia and Eritrea, Vol, 3, Pittosporaceae to Araliaceae. Addis Ababa and Uppsala; 1989. p. 1-659.

34. Edwards S, Tadesse M, Hedberg I. Flora of Ethiopia and Eritrea, Vol.2, Canellaceae to Euphorbiaceae, the National Herbarium, Addis Ababa and Uppsala; 1995. p. i-xix \& 1-456.

35. Edwards S, Demissew S, Hedberg I. Flora of Ethiopia and Eritrea, Vol. 6, Hydrocharitaceae-Arecaceae, Addis Ababa and Uppsala; 1997. p. i-xxviii \& 1-586.

36. Hedberg I, Edwards S, Nemomissa S. Flora of Ethiopia and Eritrea, Vol. 4 (1), Magnoliaceae-Flacourtiaceae, Addis Ababa and Uppsala; 2003. p. i-xiii \& 1-532.

37. Phillips O, Gentry AH, Reynel C, Wilkin P, Galvez DBC. Quantitative ethnobotany and Amazonian conservation. Conserv Biol. 1994;8:225-48.

38. Martin GJ. Ethnobotany. A methods manual, WWF for Nature International. London: Chapman and Hall; 1995. pp. 265-70.

39. Alexiades MN. Selected guidelines for ethnobotanical research: a field Manual, the New York botanical garden press, Bronx, New York; 1996. p. 167-241.

40. Hunde D, Asfaw Z, Kelbessa E. Use and management of Ethnoveterinary medicinal plants by indigenous people in Boosat, Welenchiti area. Ethiop J Bio Sci. 2004;3:113-32.

41. Estomba D, Ladio A, Lozada M. Medicinal wild plant knowledge and gathering patterns in Mapuche community from Northwestern Patagonia. J Ethnopharmacol. 2006;103:109-19.

42. Yineger $\mathrm{H}$, Yewhalaw D, Teketay D. Ethnomedicinal plant knowledge and practice of the Oromo ethnicgroup in southwestern Ethiopia. $J$ Ethnobiol Ethnomed. 2008;4:1-10.

43. Yigezu Y, Berihun D, Yenet W. Ethnoveterinary medicines in four districts of Jimma zone, Ethiopia: cross sectional survey for plant species and mode of use. BMC Vet Res. 2014;10:2-12.

44. Miller NJ, Ruiz-Larrea MB. Flavonoids and other plant phenols in the diet: their significance as antioxidants. J Nutr Environ Med. 2002;12:39-51.

45. Yineger H, Kelbessa E, Bekele T, Lulekal E. Ethnoveterinary medicinal plants at Bale Mountains National Park. Ethiopia J Ethnopharmacol. 2007;112:55-70.

46. Mesfin F, Demissew S, Teklehaymanot T. An ethnobotanical study of medicinal plants In Wonago Woreda, SNNPR, Ethiopia. J. Ethnobiol. Ethnomedicine. 2009; 5:1-18. 
47. Khan I, AbdElsalam MN, Fouad H, Tariq A, Ullah R, Adnan M. Application of ethnobotanical indices on the use of traditional medicines against common diseases. Evid Based Complement Alternat Med. 2014; 2014: 1-21.

48. Bekalo TH, Demissew S, Asfaw Z. An ethnobotanical study of medicinal plants used by local people in the lowlands of Konta Special Woreda, southern nations, nationalities and peoples regional state. Ethiopia J Ethnobiol Ethnomed. 2009;5:1-15.

49. Hassan HU, Murad W, Tariq A, Ahmad A. Ethnoveterinary study of medicinal plants in Malakand Valley, District Dir (Lower), Khyber Pakhtunkhwa, Pakistan. Ir Vet J. 2014;67:2-6.

50. Eshetu GR, Dejene TA, Telila LB, Bekele DF. Ethnoveterinary medicinal plants: preparation and application methods by traditional healers in selected districts of southern Ethiopia. Vet World. 2015;8:674-84.

51. Trotter RT, Logan MH. Informant consensus: a new approach for identifying potentially effective medicinal plants. In: Plants in Indigenous Medicine and Diet, Biobehavioral approaches. Bedford Hills: Redgrave Publishing Company; 1986. pp. 90-112.

\section{Figures}

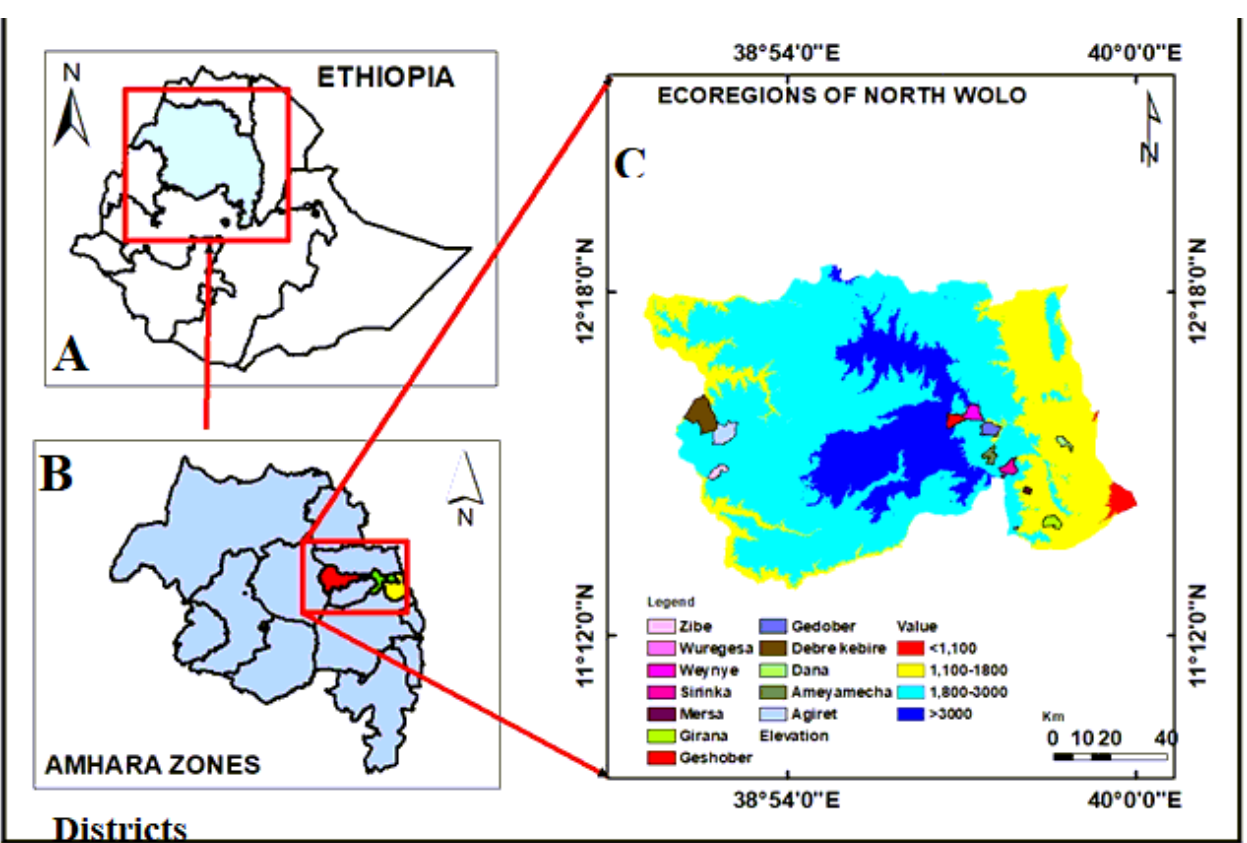

Meket

Gubalafto

Habru

Figure 1

Geographical location of the study area (A) political map of Ethiopia, (B) North Wollo administrative zone of the Amhara regional state by agroclimatic zonation (study provinces) and (C) the study sites (12) in each of the district (4) by agroclimatic conditions 

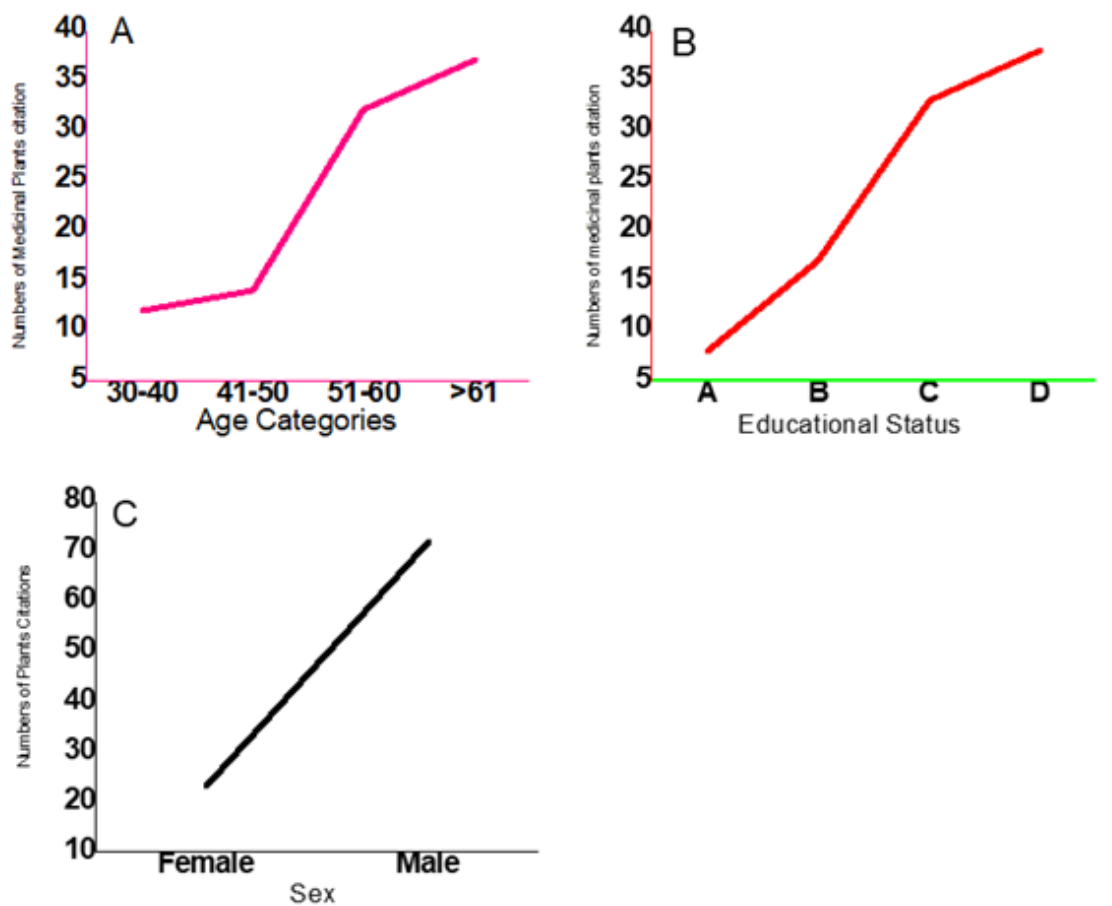

Figure 2

The cross tabulation chi-square on the numbers of ethnoveternary plants citation versus (A) age categories, (B) educational status (whereby the letter " $\mathrm{A}$ " indicates literate, " $\mathrm{B}$ " secondary education, " $\mathrm{C}$ " able to read and write and " $\mathrm{D}$ " no formal education) and (C) sex categories 


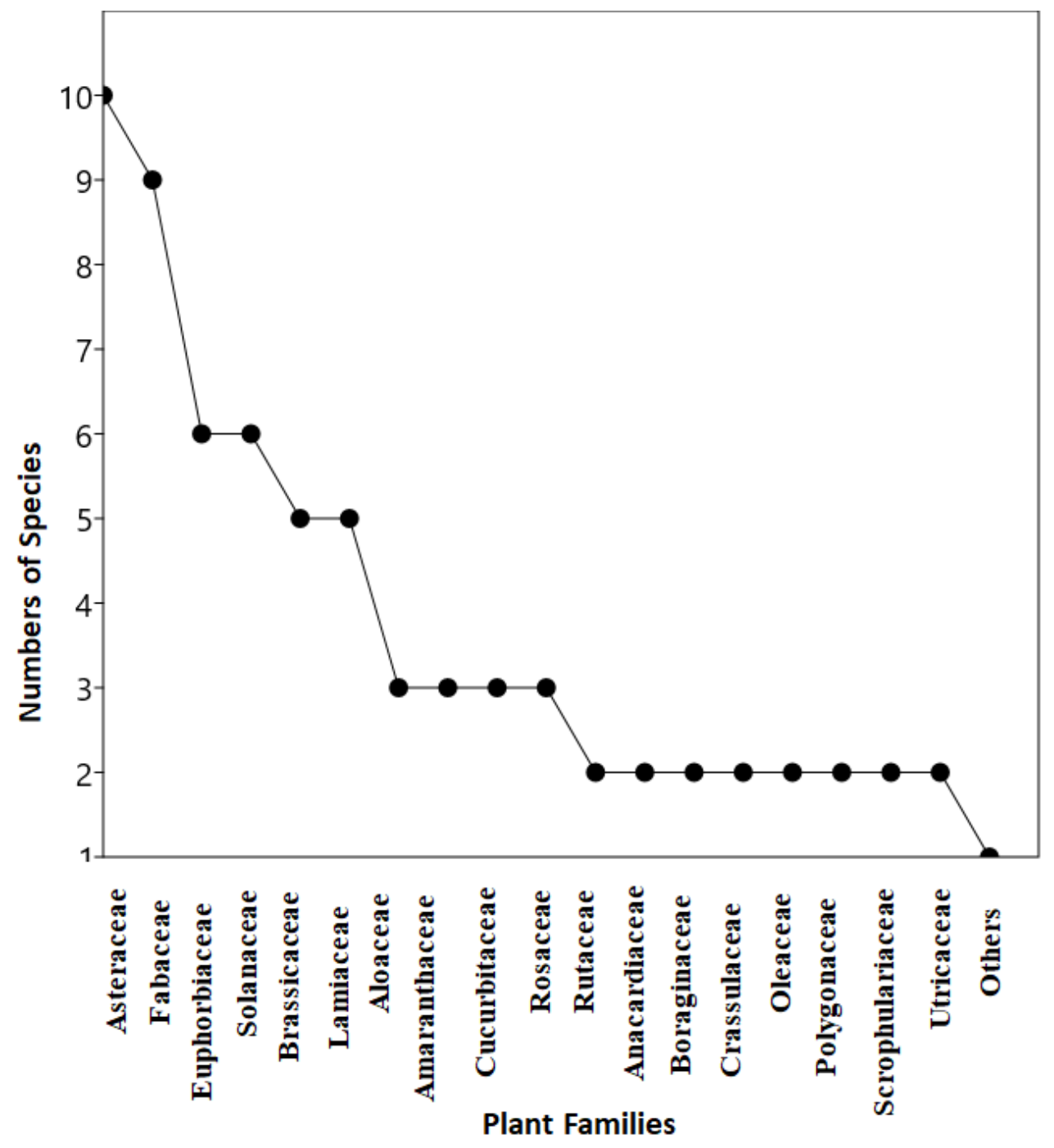

Figure 3

The distribution of ethnoveternary plants along with different plant families 

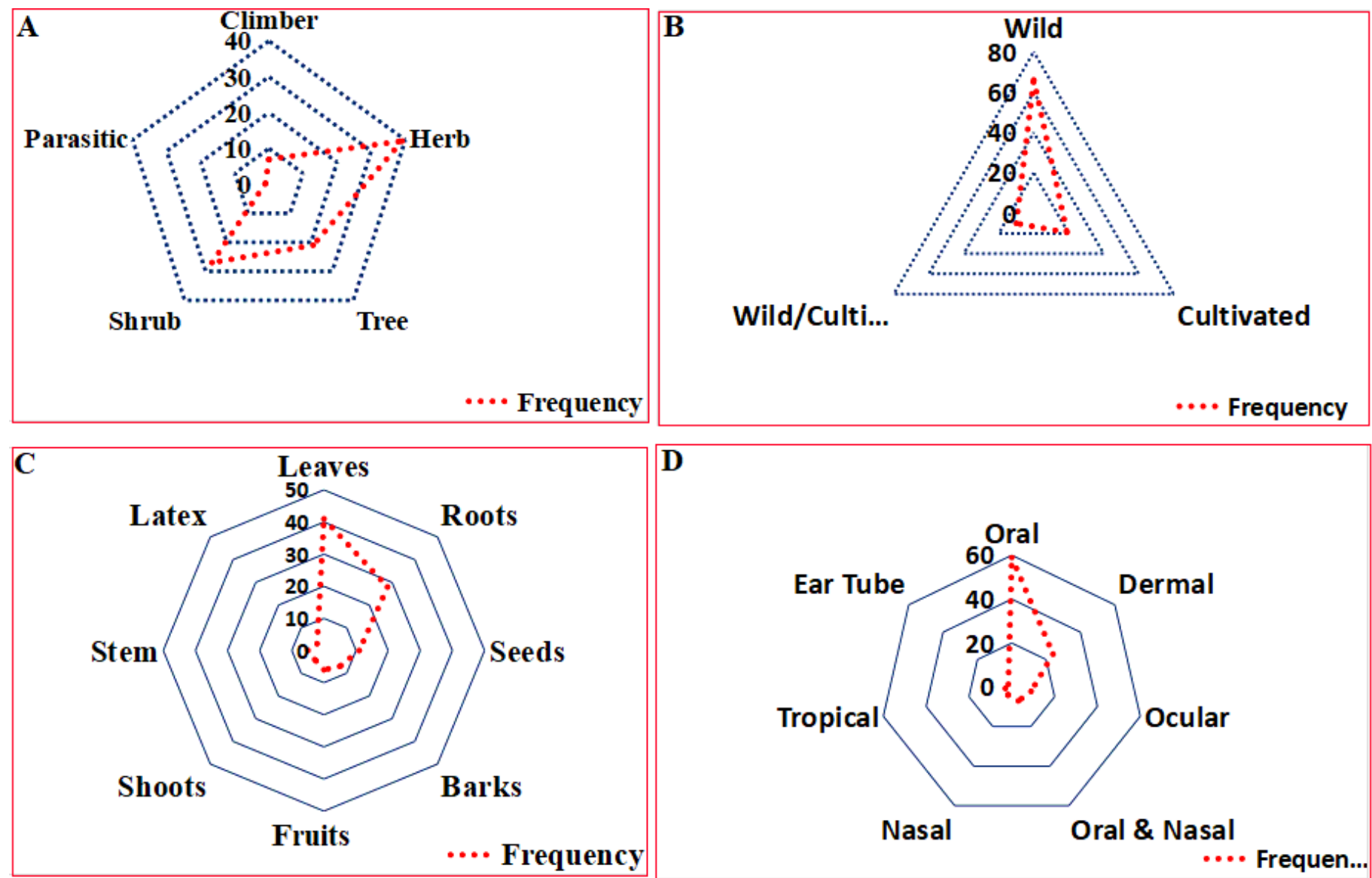

\section{Figure 4}

Radar charts used to show (A) the growth habits of the ethnoveternary plants collected and used by the local people in the surveyed agroclimatic zones, (B) the main habitats of the medicinal plants resource in the three provinces, (C) frequently used medicinal plant parts for herbal formulation to treat livestock diseases and (D) the most common routes of administration of the livestock remedies

\section{Supplementary Files}

This is a list of supplementary files associated with this preprint. Click to download.

- 8.Supplementary.xlsx 